\title{
STUDY OF FACTORS AFFECTING THE IN VITRO RELEASE OF DICLOFENAC SODIUM FROM HYPROMELOSE-BASED GELS
}

\author{
Elena Bezuglaya, Hanna Ivashchenko, Nikolay Lyapunov, Igor Zinchenko, \\ Anna Liapunova, Yurij Stolper, Aleksii Liapunov, Tatiana Pukhovaya
}

\begin{abstract}
The aim of our study was to identify factors affecting the in vitro release of diclofenac sodium (DS) from hypromellosebased gels.

Materials and methods. Gels with hypromellose (HPMC) and liquids without HPMC were studied by viscosity-rotating viscometer method and spin probe electron paramagnetic resonance spectroscopy. Rheograms were used to determine the flow behavior and the apparent viscosity, and the EPR spectra were used to determine the rotational correlation time $\left(\tau_{-1}\right)$ of the dissolved spin probes. The in vitro release tests were performed using vertical diffusion cells according to a validated procedure. The assay of DS and isopropyl alcohol (IPA) in the receptor medium was performed by high performance liquid chromatography $(H P L C)$ and gas chromatography $(G C)$ according to validated procedures, and the water content was determined using semi-micro method.
\end{abstract}

Results. The apparent viscosity of the gels increased with increasing HPMC content and depended on the HPMC grade. The high apparent viscosity of the gels did not affect the values of $\tau_{-1}$ of the dissolved spin probes. In viscous gels and Newtonian fluids, the composition of which corresponded to the dispersion medium of gels, the values of $\tau_{-1}$ were identical and were in the range of rapid rotation, which is a prerequisite for similar and rapid release of the dissolved substances from gels and liquids. It was shown that the HPMC-based gel and Newtonian liquid without HPMC in terms of in vitro release parameters DS and IPA were equivalent. During in vitro testing the release of dissolved DS increased with increasing its concentration in the gel and depended on the dispersed state of DS. When the content of IPA was changed from $45.0 \%$ to $22.5 \%$, the water absorption by the gel and the release of IPA decreased, and the release of DS increased, which was due to the decrease in the solubility of DS in the gel.

Conclusions. HPMC, which provided high apparent viscosity of the gels, did not affect the value of $\tau_{-1}$ of the dissolved spin probes and the in vitro release of DS from the gels. The gel and Newtonian liquid were equivalent in terms of in vitro release of DS and IPA. The release of DS altered proportionally with the concentration of DS and depended on its dispersed state. As the content of IPA decreased, the release of IPA decreased, but the release of DS increased because of the decrease in the solubility of the DS in the gel

Keywords: hypromellose, gel, liquid, diclofenac sodium, isopropyl alcohol, viscosity, rotational correlation time ( $\left.\tau_{-1}\right)$, in vitro release test (IVRT)

\section{How to cite:}

Bezuglaya, E., Ivashchenko, H., Lyapunov, N., Zinchenko, I., Liapunova, A., Stolper, Y., Liapunov, A., Pukhovaya, T. (2021). Study of factors affecting the in vitro release of diclofenac sodium from hypromelose-based gels. ScienceRise: Pharmaceutical Science, 5 (33), 12-31. doi: http://doi.org/10.15587/2519-4852.2021.243040

(C) The Author(s) 2021

This is an open access article under the Creative Commons CC BY license hydrate

\section{Introduction}

Gels are semi-solid preparations for cutaneous application; they consist of liquids gelled by means of suitable gelling agents [1]. Various polymers such as carbomers and cellulose derivatives are used to form hydrogels [2].

It was previously shown that the formation of gels with carbomers which were characterized by plastic flow behaviour and high apparent viscosity did not cause an increase in the viscosity of the gel dispersion medium. Dissolved in the gel base spin probes remained in a state of rapid isotropic rotation; that could be a prerequisite for the rapid release of dissolved active substances from such gels [3]. However, during those experiments the effect of this factor on the release of active substances was not studied. Also it was shown that the interaction of the spin probe 4-amino-TEMPO and carboxylate anions of carbomers caused an increase in the rotational correlation time $\left(\tau_{-1}\right)$ of this spin probe in the gels within a certain $\mathrm{pH}$ range. This interaction can affect the release of active substances with amino groups in the molecules, or prevent their introduction into formulations of gels based on carbomers [3]. However, that article does not contain any results of studies with other polymers, such as hypromellose (HPMC), which molecules do not possess reactive carboxylate anions.

The data in regard to the functional purpose of HPMC in different dosage forms are summarized in the scientific literature $[2,4]$. In preparations for oral administration, HPMC is used as a binder and as a substance for coating tablets, as well as for the formation of matrices that provide modified release of active substances $[2,4]$. Due to its mucoadhesive properties, HPMC is used in oromucosal drug delivery systems including 
mucoadhesive tablets and films [4]. In liquid and semisolid preparations, HPMC is used as a modifier of rheological properties and a stabilizer of dispersed systems [2]. In recent years, scientific publications contain the results of numerous studies on the effects of HPMC on the release of various active substances from granules [5], hydrogel films [6], and tablets (including modifiedrelease ones) [7-10]. There are no publications concerning the effect of HPMC on the release of active substances from topical gels. The use of HPMC in semi-solid preparations is less common compared to carbomers. The example is Diclac $^{\circledR}$ gel $5 \%$ (Sandoz, Slovenia), which contains diclofenac sodium (DS), HPMC, isopropyl alcohol (IPA), macrogol 7 glycerol cocoate and purified water $[11,12]$.

The inherent side effects of diclofenac could be minimized by its cutaneous application in the form of gels due to reduced systemic absorption $[13,14]$. It was proved that diclofenac, when applied topically in the form of gel, which contains IPA, was able to penetrate through skin and was found in therapeutic concentrations in synovial tissues and synovial fluid of the knee joint [15]. Such properties provided an effective analgesic and anti-inflammatory effect in the treatment of osteoarthritis using gels with diclofenac $[14,15]$.

At the stage of pharmaceutical development, the equivalence of generic products with non-steroidal antiinflammatory drugs in the form of gels and the corresponding reference medicinal products should be studied by the results of comparative in vitro release tests (IVRT).

The methodology of comparative tests in regard to the in vitro release of active substances from topical dosage forms and acceptance criteria are outlined in the USP General Chapter $<1724>$ «Semisolid Drug Products Performance Tests» [16]. A plot of the amount of active substance released per unit membrane area $\left(\mu \mathrm{g} / \mathrm{cm}^{2}\right)$ versus square root of time should yield a straight line. Compared drugs are considered equivalent if the $90 \%$ confidence interval for the ratio of release rates $(\mathrm{R})$ of the active substance for test and reference products, converted to percent, is within the range of 75.00-133.33\%.

The draft guideline to evaluate the equivalence of topical products was also prepared by the European Medicines Agency (EMA) [17]. According to this document the interval of $90-111 \%$ is considered acceptable for parameter $\mathrm{R}$. In addition, it is proposed to compare the cumulative amount of released substance (A), i.e., its content in the receptor medium at the last sampling time point; acceptance criterion for this parameter is the same 90-111\%. Such approaches and criteria are disputable and they are critically discussed in the scientific literature [18].

Beyond that, the formulation, microstructure and physicochemical properties of SSP should be compared, for example, rheological properties, density, etc., to confirm the pharmaceutical equivalence [17, 19]. Therefore, during pharmaceutical development it makes sense to identify the factors which affect the release of the active substance.

There are a lot of data in the scientific literature in regard to the comparative studies of the in vitro release of DS from gels produced by various manufacturers [20], as well as to the comparative studies of the in vitro release of diclofenac diethylamine from emulgels based on carbomers, rheological properties of those emulgels and bioequivalence studies of diclofenac [21]. The authors concluded that a difference of more than $\pm 10 \%$ between the rheological parameters of the test and reference products had not lead to a significant difference in the in vitro release parameters or bioavailability of diclofenac.

The results of the studies of the effect of HPMC on the release of active substances from topical semisolid preparations are not presented in research publications; the pharmaceutical factors that may be crucial for the in vitro release of the active substances (in particular, diclofenac salts) from gels are not identified. However, such information is extremely important for the rational planning of pharmaceutical development in order to create generic preparations for cutaneous use that are equivalent to the reference medicinal product. In view of this, the main goal of the study was established.

The aim of our study was to identify factors affecting the in vitro release of diclofenac sodium from hypromellose-based gels.

\section{Planning (methodology) of the research}

The objects of research were:

1) HPMC-based hydrogels,

2) hydrogels, qualitative compositions of which were similar to formulation of Diclac ${ }^{\circledR}$ gel $5 \%[11,12]$,

3) liquids without HPMC but with the same other constituents contained in hydrogels.

The IPA content as an osmotically active substance, which can affect the passive diffusion of DS from gels and liquids, was varied in gels and liquids [22]. It was necessary to determine flow behaviour of the gels and liquids as well as their apparent or dynamic viscosity $[1,23]$. According to the spectra of the EPR of spin probes, dissolved in gels and liquids, it was necessary to determine the values of $\tau_{-1}$, which are directly proportional to the microviscosity of their local environment, and isotropic constants $\left(\mathrm{A}_{\mathrm{N}}\right)$ characterizing the micropolarity [24]. The impact of HPMC on the apparent viscosity of gels and $\tau_{-1}$ of spin probes should have been assessed. Also it was necessary to compare the values $\tau_{-1}$ of spin probes with various functional groups in gels and solutions. Thus, the information about possible physicochemical interactions between spin probes and HPMC that could potentially affect the in vitro release of active substances with the same functional groups could be received.

After that it was necessary to study the factors which could affect the in vitro release of DS from gels/liquids such as:

1) the different rheological properties (flow behaviour and viscosity) due to the presence or absence of HPMC;

2) the different content of DS and IPA in the gels,

3) the different dispersed state of DS (solution or dispersion phase suspended in a saturated solution).

In vitro release tests were conducted using vertical diffusion chambers. For this purpose, it was necessary to develop and validate an analytical procedure for quantitative determination of DS in receptor medium by HPLC, which could provide the analysis of a large number of samples in a short period of time $[1,23,25]$. Some studies on the validation of the IVRT method should also have been performed [16-18, 26]. 
The results of comparative studies in regard to release of DS were assessed against the acceptance criteria outlined in the EMA draft guidelines [17] and the USP General Chapter <1724> [16]. The results of the research should have been used to identify significant pharmaceutical factors influencing the release of DS from the gels. Taking these factors into account, it was necessary to propose the adequate measures for standardisation of diclofenac gels in order to reduce the risks associated with batch-to-batch variability and production of nonequivalent batches as regards in vitro release of DS. The solubility of DS in mixed solvents water - IPA was studied to explain the effect of IPA content on DS release.

The diffusion through the permeable membrane is due to the difference between the osmotic pressure of the gel/liquid and the receptor medium (water). In this case the multidirectional processes of diffusion take place:

1) release of low molecular weight substances into the receptor chamber and gel/liquid.

2) permeation of water into the compartment with

Therefore, it was also advisable to study the release of IPA into the receptor chamber and the diffusion of water into the chamber with gel/solution. That was why it was necessary to develop and validate the analytical procedure for the assay of IPA in the receptor medium by GC [1, 23, 25], and determination of water content in the chamber with gel/liquid should have been performed by semi-micro method $[1,23]$.

\section{Materials and methods}

Diclofenac sodium (DS) («Amoli Organics Pvt. Ltd», India) as well as the following excipients were used:
- HPMC of different types providing various apparent viscosity of gels: Walocel HM 4000 PA 2208, Walocel HM 4000 PA 2906 and Walocel HM 4000 PA 2910, Walocel HM 15000 PA 2208, Walocel HM 100000 PA $2208(«$ Evonik») $[1,2]$;

- isopropyl alcohol (IPA);

- macrogol 7 glycerol cocoate $\left(\right.$ Cetiol $\left.^{\circledR} \mathrm{HE}\right)$ $(« \mathrm{BASF} »)$;

- purified water (hereinafter - water) [1].

The substances met the requirements established in the relevant monographs of the European Pharmacopoeia [1].

Gels which contained HPMC at concentration $1 \%$, $2 \%$ and $3 \% \mathrm{~m} / \mathrm{m}$ were studied. Gels were prepared by dissolving HPMC in water followed by degassing. Liquids without HPMC as well as gels and liquids with different content of DS or IRA were also the subjects of the research; their compositions are shown in Table 1. Aqueous solutions of spin probes as well as gels No. 1 and No. 2, liquids No. 1 and No. 2 and gels based on HPMC of different types (HPMC content $3 \% \mathrm{~m} / \mathrm{m}$ ) with spin probes dissolved in them were studied.

The medicinal product Diclac ${ }^{\circledR}$ gel $5 \%$ («Sandoz», Slovenia) and gel containing $5 \%$ of DS, produced by other manufacturer (hereinafter - Diclofenac gel $5 \%$ ) were under study. The dispersed state of DS in gels was determined by optical microscopy $(2.9 .37)$ [1, 23] using a microscope with micrometer «Krüss MBL-2100» («A. Krüss Optronic», Germany). In the tested gels/liquids (Table 1) and in the product Diclac ${ }^{\circledR}$ gel $5 \%$ DS was in dissolved state but in the product Diclofenac gel $5 \%$ DS was as a dispersed phase (Fig. 1) suspended in saturated solution of this substance.

Table 1

Composition of gels and liquids under study

\begin{tabular}{|c|c|c|c|c|c|c|}
\hline \multirow{2}{*}{ Substance } & \multicolumn{6}{|c|}{ Content, $\% \mathrm{~m} / \mathrm{m}$} \\
\hline & Gel No. 1 & Liquid No. 1 & Gel No. 2 & Liquid No. 2 & Gel No. 3 & Gel No. 4 \\
\hline $\mathrm{DS}^{1}$ & 5.0 & 5.0 & 5.0 & 5.0 & 2.5 & 7.5 \\
\hline IPA & 45.0 & 45.0 & 22.5 & 22.5 & 45.0 & 45.0 \\
\hline Cetiol $^{(R)} \mathrm{HE}$ & 6.0 & 6.0 & 6.0 & 6.0 & 6.0 & 6.0 \\
\hline HPMC $^{1}$ & 3.0 & 0 & 3.0 & 0 & 3.0 & 3.0 \\
\hline Water & ad 100.0 & ad 100.0 & ad 100.0 & ad 100.0 & ad 100.0 & ad 100.0 \\
\hline
\end{tabular}

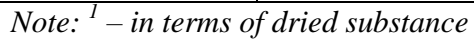
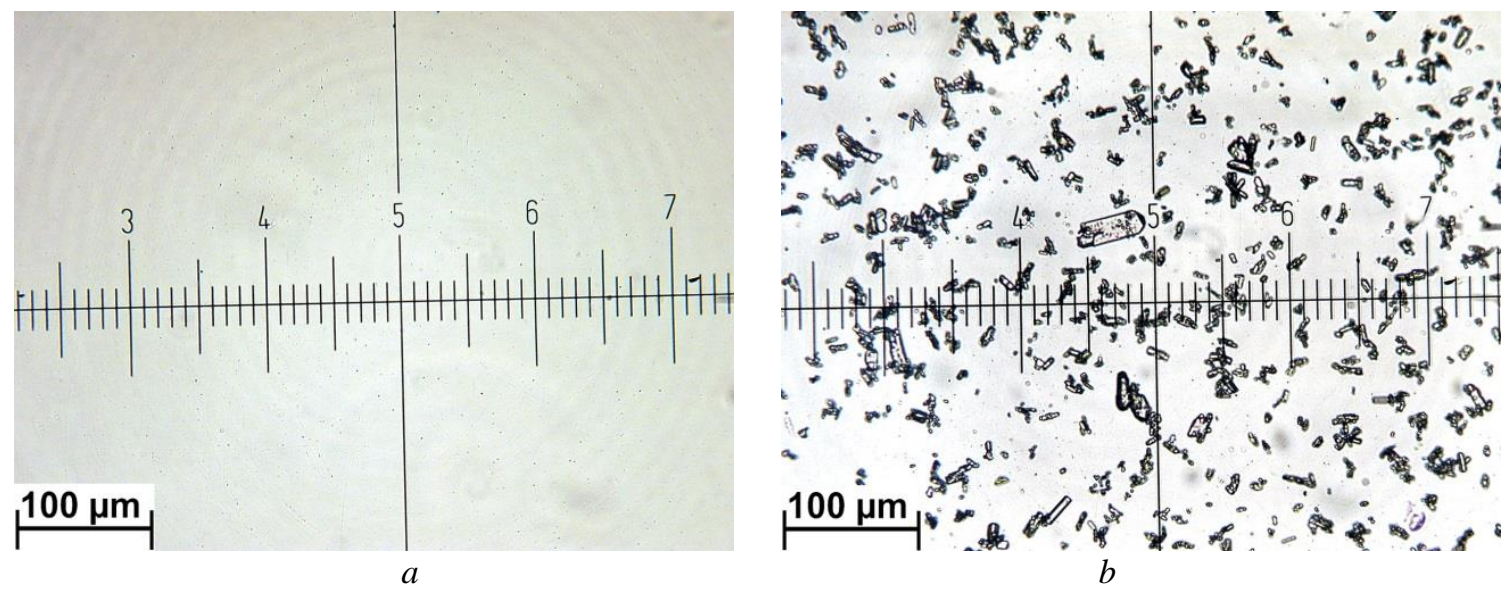

Fig. 1. Micrographs of the medicinal products:

$a-$ Diclac $^{\circledR}$ gel $5 \%$ (batch KT8718); $b$-Diclofenac gel $5 \%$ (batch 411019); at $\times 150$ 
Rheological research was performed by rotating viscometer method (2.2.10) [1, 23]. Rheograms (plots of the shear stress $\left(\tau_{\mathrm{r}}\right)$ versus the shear rate $\left.\left(D_{\mathrm{r}}\right)\right)$ were obtained at $25{ }^{\circ} \mathrm{C}$ using a rotating viscometer «Rheolab QC» with coaxial cylinders CC-27 (for gels) and DG-42 (for liquids) («Anton Paar $\mathrm{GmbH»;} \mathrm{software}$ RHEOPLUS, version 2.66). Rheograms were used to characterize the flow behaviour as well as to determine the apparent viscosity of gels and the dynamic viscosity of Newtonian liquids $(\eta)[1,23]$.
The EPR spectroscopy was used for the research [24]. The following 5 hydrophilic spin probes with different functional groups were used: TEMPO $\left(\mathrm{C}_{9} \mathrm{H}_{18} \mathrm{NO}\right.$; $M_{r}$ 156,25; CAS: [2564-83-2]), TEMPON (4-oxoTEMPO) ( $\mathrm{C}_{9} \mathrm{H}_{16} \mathrm{NO}_{2} ; M_{r} 170,23 ; \mathrm{CAS}:$ [2896-70-0]), TEMPOL (4-hydroxy-TEMPO) $\left(\mathrm{C}_{9} \mathrm{H}_{18} \mathrm{NO}_{2} ; M_{r}\right.$ 172,24; CAS: [2226-96-2]), 4-amino-TEMPO $\left(\mathrm{C}_{9} \mathrm{H}_{19} \mathrm{~N}_{2} \mathrm{O} ; M_{r}\right.$ 171,26; CAS: [14691-88-4]), 3-carboxy-2,2,5,5-tetramethyl-1-pyrrolidinyloxy (PCA) $\left(\mathrm{C}_{9} \mathrm{H}_{16} \mathrm{NO}_{3} ; M_{r}\right.$ 186,23; CAS: [2154-68-9]):

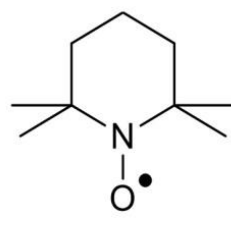

TEMPO<smiles>CC1(C)CC(=O)CC(C)(C)N1[O]</smiles>

TEMPON<smiles>CC1(C)CC(O)CC(C)(C)N1[O]</smiles>

TEMPOL<smiles>CC1(C)CC(N)CC(C)(C)N1[O]</smiles>

4-amino-

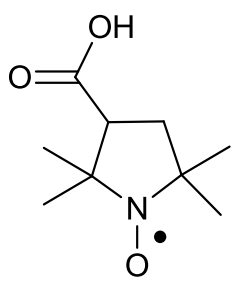

PCA

TEMPO

The probes were added into liquids and gels at a concentration of $10^{-4} \mathrm{~mol} / \mathrm{l}$. EPR spectra were obtained using an EPR Spectrometer CMS8400 («Adani»; software EPRCMD) at $(25.0 \pm 1.0){ }^{\circ} \mathrm{C}$. Using EPR spectra some parameters were determined such as the hyperfine splitting constant $\left(A_{N}\right)$, which characterizes the micropolarity of the environment in the vicinity of radical, as well as the rotational correlation time of probes $\left(\tau_{-1}\right)$, which according to the Stokes-Einstein equation is directly proportional to the effective radius of the molecule $(\mathrm{R})$ and to the microviscosity of its local surrounding $(\eta)$ and inversely proportional to the absolute temperature (T) [24]:

$$
\tau=\left(4 \cdot \pi \cdot \mathrm{R}^{3} \cdot \eta\right) / 3 \cdot \mathrm{k} \cdot \mathrm{T}
$$

Rotational correlation time of spin probes $\left(\tau_{-1}\right)$ was calculated by the following equation [24]:

$$
\tau_{-1}=\left(\sqrt{\frac{\mathrm{h}_{0}}{\mathrm{~h}_{-1}}}-1\right) \cdot \Delta \mathrm{H}_{0} / 3,6 \cdot 10^{9},
$$

where $h_{0}$ and $h_{-1}$ are the peak-to-peak heights of the central and high-field components of EPR spectrum and $\Delta \mathrm{H}_{0}$ is the width of central component (Gs).

The IVRT experiments in regard to DS release from liquids and gels were performed using vertical diffusion cells and semipermeable cellulose membranes (GOST 7730-89); the membranes were pre-soaked in the receptor medium (water $R$ ) for 24 hours. The tests were performed at $32{ }^{\circ} \mathrm{C}$; in order to evaluate the robustness of the IVRT method to minor perturbations in temperature two additional IVRT runs were conducted at temperatures $30{ }^{\circ} \mathrm{C}$ and $34{ }^{\circ} \mathrm{C}$. A circulating thermostat Julabo F12-ED («Julabo Labortechnik GmbH», Germany) was used to maintain a necessary temperature (with an accuracy of $\pm 0.5^{\circ} \mathrm{C}$ ). The medium in the receptor chamber was stirred by magnetic stirrer with mixing rate $600 \mathrm{rpm}$. Samples (1,0 ml) were collected from receptor chamber at $0.5,1,2$,
$3,4,5$, and $6 \mathrm{~h}$ after application of tested product and the volume withdrawn was replaced with stock receptor medium (water R). The concentrations of DS in receptor medium at different sampling time were measured and DS amount $(\mu \mathrm{g})$ released at given time per unit area $\left(\mathrm{cm}^{2}\right)$ was calculated for each sample. The results were assessed according to the requirements of EMA draft guidelines [17] and USP General Chapter <1724> [16].

Quantitative determination of DS in the IVRT samples was performed by HPLC (2.2.29) [1, 23] according to the developed analytical procedure using Shimadzu Prominence-i LC-2030C 3D liquid chromatograph with a diode-array detector («Shimadzu», Japan; software: LabSolutions Lite, version 5.82).

Analytical procedure. Test solution. Filtered sample (receptor medium containing released DS) to be examined.

Reference solution. The solution of Diclofenac Sodium BP CRS (Cat. No. 619) in the mixture methanol $R-$ water $R$ (10:190) $250 \mu \mathrm{g} / \mathrm{ml}$.

Chromatographic conditions:

- isocratic elution;

- mobile phase: acetonitrile for chromatography $R$ - buffer solution 3.0 (solution of potassium dihydrogen phosphate $R(1.36 \mathrm{~g})$ in water for chromatography $R$ $(1000 \mathrm{ml})$ adjusted to $\mathrm{pH}(3.0 \pm 0,05)$ by phosphoric acid R) $(60: 40)$;

- column: stainless-steel chromatographic column, $125 \times 4.0 \mathrm{~mm}$, packed with end-capped octylsilyl silica gel for chromatography $R \quad(5 \mu \mathrm{m})$ LiChrospher ${ }^{\circledR}$ 60 RP-select B, «Merck», Cat. No. 1.50981.0001);

- flow rate: $1.0 \mathrm{ml} / \mathrm{min}$;

- detection: at $282 \mathrm{~nm}$;

- injection: $5 \mu \mathrm{l}$;

- temperature: $40{ }^{\circ} \mathrm{C}$

- run time: $\sim 5 \mathrm{~min}$; Rt of DS $2.8 \mathrm{~min}$.

System suitability:

- column performance calculated by the peak due to diclofenac in the chromatogram obtained with the 
reference solution should be at least 2500 theoretical plates;

- symmetry factor and relative standard deviation should meet the requirements of State Pharmacopoeia of Ukraine.

Weighing was performed using analytical balances AUW 120D («Shimadzu», Japan); the solutions were prepared by mass-volume technique using volumetric amber glass flasks (class A, «Simax», Czech Republic); the potentiometric determinations of $\mathrm{pH}(2.2 .3)$ [1, 23] were conducted using a $\mathrm{pH}$ meter Metrohm 827 lab («Metrohm», Switzerland).

Validation of procedure for quantitative determination of DS was carried out according to the generally accepted methodology [25, 27]. Acceptance criteria for validation characteristics were calculated in accordance with the requirements of general article 5.3.N.2 of State Pharmacopoeia of Ukraine [25].

Validation of the IVRT procedure was performed according to recommendations laid down in scientific publications [16-18, 26]. The following characteristics were assessed:

- membrane inertness; a membrane should not bind to DS and prevent the diffusion of DS; the concentration of DS in the model solution after contact with the membrane should be at least $95 \%$ compared to the control experiment;

- solubility of DS in the receptor medium (water $R$ ) which should be more than at least 10 times higher than the highest DS concentration in the samples obtained during experiments for IVRT validation;

- linearity, precision and reproducibility which were proved by the results of three runs of IVRT performed on three different days using gel No.1 containing $5.0 \%$ of DS. The plot of the amount of the substance released versus the square root of time should be linear; coefficient of determination $\left(\mathrm{R}^{2}\right)$ should be greater than 0.90 . In order to evaluate precision and reproducibility the intra- and inter-run variability were determined for the release rate - the relative standard deviation (RSD) should be less than $15 \%$ (USP criterion) or $10 \%$ (EMA criterion);

- sensitivity, specificity and selectivity which were proved by the results of the IVRT using gels containing $2.5 \%, 5.0 \%$ (nominal content) and $7.5 \%$ of DS. The IVRT procedure was considered to be sensitive if the mean release rate of DS from $2.5 \%$ and $7.5 \%$ gels was respectively lower and higher compared to $5.0 \%$ gel. The specificity of the IVRT procedure was evaluated by the proportionality of the change in the release rate of DS according to its content in the test gels. The IVRT procedure was considered to be specific if the $\mathrm{R}^{2}$ was greater than 0.90 . The IVRT procedure was considered to be selective if the ratios of release rates of DS from the gels with different content of this substance $\left(R_{2,5} \% / R_{5,0} \%\right.$ тa $\left.R_{7,5} \% / R_{5,0} \%\right)$ fell outside limits 75.00-133.33 \% (USP criterion) and 90-111\% (EMA criterion), i. e. $2.5 \%$ and $7.5 \%$ gels were non-equivalent to $5 \%$ gel. Also The IVRT procedure was considered to be selective if the ratios of release rates of DS, obtained in three runs using the same $5.0 \%$ gel, contained within acceptance interval 75.00-133.33 \% (USP criterion) and 90-111\% (EMA criterion);

- robustness in regard to temperature variations was studied by determination of average release rate of
DS from $5.0 \%$ gel at $30^{\circ} \mathrm{C}, 32{ }^{\circ} \mathrm{C}$ and $34{ }^{\circ} \mathrm{C}$. With decreasing and increasing temperature by $2{ }^{\circ} \mathrm{C}$ the average release rate should not deviate by more than $15 \%$.

- recovery was determined by the amount of DS released from the gel applied onto the membrane in the donor chamber; recovery was considered acceptable if the amount of DS released was not more than $30 \%$.

The solubility of DS was studied by the isothermal method [19], and the DS content in the saturated solution was determined by HPLC according to a validated analytical procedure.

For a comprehensive characterization of the diffusion processes, the diffusion of water into the chamber with gel/liquid (donor chamber) and the release of the IPA into the chamber with water (receptor chamber) were also determined.

The water content was determined by semimicromethod (2.5.12) [1, 23] using an automatic titrator 870 KF Titrino plus («Metrohm AG», Switzerland; software Firmware 58700025).

The IPA content in the receptor medium was determined by GC according to the developed analytical procedure using gas chromatograph Shimadzu GC-2014 with FID detector and AOC-5000 autoinjector («Shimadzu»; software: GC solution version 2.30.00).

Analytical procedure. Test solution. Filtered sample (receptor medium containing released IPA) to be examined.

Reference solution. Filtered solution of $200 \mathrm{mg}$ $(\sim 255 \mu \mathrm{l})$ of 2-Propanol USP RS (Cat. No. 1570428) in $20 \mathrm{ml}$ of water $R$.

Chromatographic conditions:

column: glass column, $110 \mathrm{~cm} \times 3.2 \mathrm{~mm}$, packed with Porapak (particle size 80-100 mesh);

carrier gas: nitrogen for chromatography $R$;

linear velocity: $30 \mathrm{ml} / \mathrm{min}$;

column temperature: $160^{\circ} \mathrm{C}$;

detector temperature: $250^{\circ} \mathrm{C}$;

injector temperature: $250^{\circ} \mathrm{C}$;

detection: flame ionosation;

injection: $1 \mu \mathrm{l}$;

run time: $~ 10 \mathrm{~min}$; Rt IPA 6.5 min.

System suitability:

- column performance calculated by the peak due to IPA in the chromatogram obtained with the reference solution should be $\geq 300$ theoretical plates;

- symmetry factor for peak due to IPA should be from 0.8 to 1.5 and the relative standard deviation should be $\leq 3.0 \%$.

Validation of procedure for quantitative determination of IPA by GC was carried out according to the accepted methodology [25, 28]. Acceptance criteria for validation characteristics were calculated in accordance with the requirements of general article 5.3.N.2 of State Pharmacopoeia of Ukraine [25].

The density $(\rho)$ of gels and solvents was measured at a certain temperature using oscillation-type density meter DMA 500 («Anton Paar GmbH», Austria; software version V1.003).

\section{Research results}

Research by rotating viscometer method and spin probes method 
Fig. 2 shows the rheograms of water solutions of Walocel HM 4000 PA 2910, and Table 2 contains data regarding their apparent viscosity. The EPR spectra of 5 spin probes in water and in the hydrogel containing $3.0 \%$ Walocel HM 4000 PA 2910 are shown in Fig. 3, and Table 3 provides some parameters of the EPR spectra.

As the concentration of HPMC increased, the type of flow changed, and the apparent viscosity of its aqueous solutions increased (Fig. 2, Table 2); at the content of HPMC $3.0 \%$ the solution became a gel with an apparent viscosity from $6600 \mathrm{~Pa} \cdot \mathrm{s}$ to $2800 \mathrm{~Pa} \cdot \mathrm{s}$ at $\mathrm{D}_{\mathrm{r}}$ from $14.6 \mathrm{~s}^{-1}$ to $82.3 \mathrm{~s}^{-1}$, which is more than 3 orders of magnitude greater than the dynamic viscosity of water.

The formation of the gel at the concentration of Walocel HM 4000 PA $29103.0 \%$ did not affect the state of the EPR spectra of water-soluble spin probes, which remained identical to their EPR spectra in water and indicated the same rapid isotropic rotation of molecular radicals in gels as in water (Fig. 3, Table 3). According to the parameters of the EPR spectra, the spin probes rotated in a liquid medium that was water. The rotational correlation times $\left(\tau_{-1}\right)$ of individual spin probes (and, respectively, the viscosity of their local surrounding) in the gel and water were close to each other and differed within the determinate error (Table 3 ), that at such rotational speeds of spin probes could be $20-25 \%$ [24]. That is, the increase in the apparent viscosity of the gel compared to the dynamic viscosity of water by approximately 2800-6600 times had al- most no effect on $\tau_{-1}$ and, respectively, on the viscosity of the local surrounding of the spin probes with different functional groups dissolved in gels.

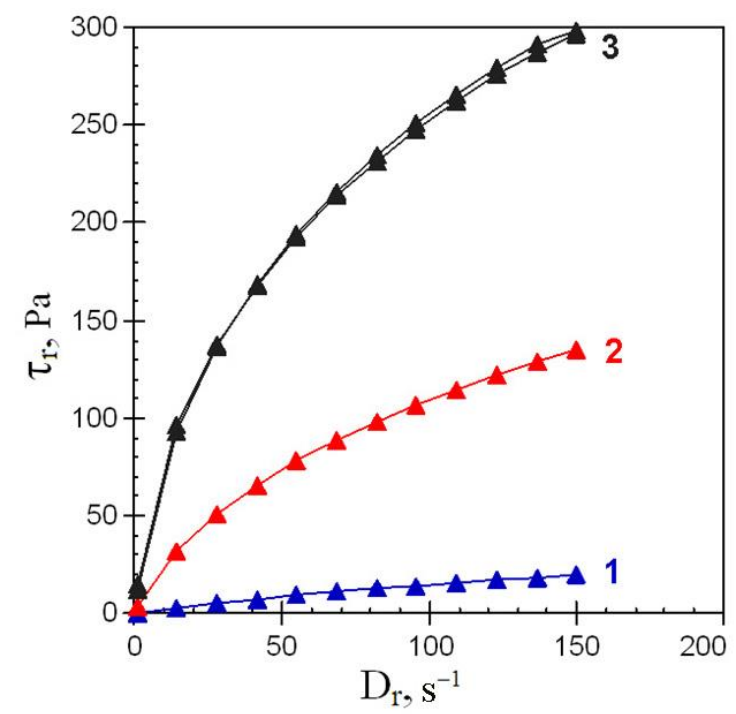

Fig. 2. Rheograms (at $25^{\circ} \mathrm{C}$ ) of the aqueous solutions of Walocel HM 4000 PA 2910 with its content: $1-1.0 \%$, $2-2.0 \%, 3-3.0 \%$

Data in regard to the apparent viscosity of gels based on HPMC of different types as well as the $\tau_{-1}$ for spin probe TEMPON in these gels are shown in Table 4.

Apparent viscisity ( $\eta$ ) of aqueous solutions of HPMC Walocel HM 4000 PA 2910 at $25^{\circ} \mathrm{C}$

Table 2 and different shear rates $\left(\mathrm{D}_{\mathrm{r}}\right)$

\begin{tabular}{|c|c|c|c|}
\hline \multirow{2}{*}{$\mathrm{D}_{\mathrm{r}}, \mathrm{s}^{-1}$} & \multicolumn{3}{|c|}{$\eta(\mathrm{Pa} \cdot \mathrm{s})$ at Walocel HM 4000 PA 2910 content: } \\
\cline { 2 - 4 } & $1.0 \%$ & $2.0 \%$ & $3.0 \%$ \\
\hline 14.6 & 0.18 & 2.20 & 6.63 \\
\hline 41.6 & 0.17 & 1.58 & 4.04 \\
\hline 82.3 & 0.15 & 1.19 & 2.82 \\
\hline
\end{tabular}

Parameters of the EPR spectra of the spine probes (see Fig. 2) in water and in the gel containing $3.0 \%$ Walocel HM 4000 PA 2910 at $25^{\circ} \mathrm{C}$

\begin{tabular}{|c|c|c|c|c|}
\hline \multirow{2}{*}{ Object } & Spine probe & $\mathrm{A}_{\mathrm{N}}, \mathrm{mT}$ & $\tau_{-1} \cdot 10^{11}, \mathrm{~s}$ & Spectrum state \\
\hline Water & TEMPON & 1.62 & 0.82 & triplet \\
\hline Gel & TEMPON & 1.62 & 0.82 & triplet \\
\hline Water & TEMPOL & 1.72 & 0.95 & triplet \\
\hline Gel & TEMPOL & 1.72 & 0.91 & triplet \\
\hline Water & TEMPO & 1.74 & 0.38 & triplet \\
\hline Gel & TEMPO & 1.74 & 1.23 & triplet \\
\hline Water & 4-amino-TEMPO & 1.70 & 1.24 & triplet \\
\hline Gel & 4-amino-TEMPO & 1.70 & 1.03 & triplet \\
\hline Water & PCA & 1.64 & 0.95 & triplet \\
\hline Gel & PCA & 1.64 & & \\
\hline
\end{tabular}




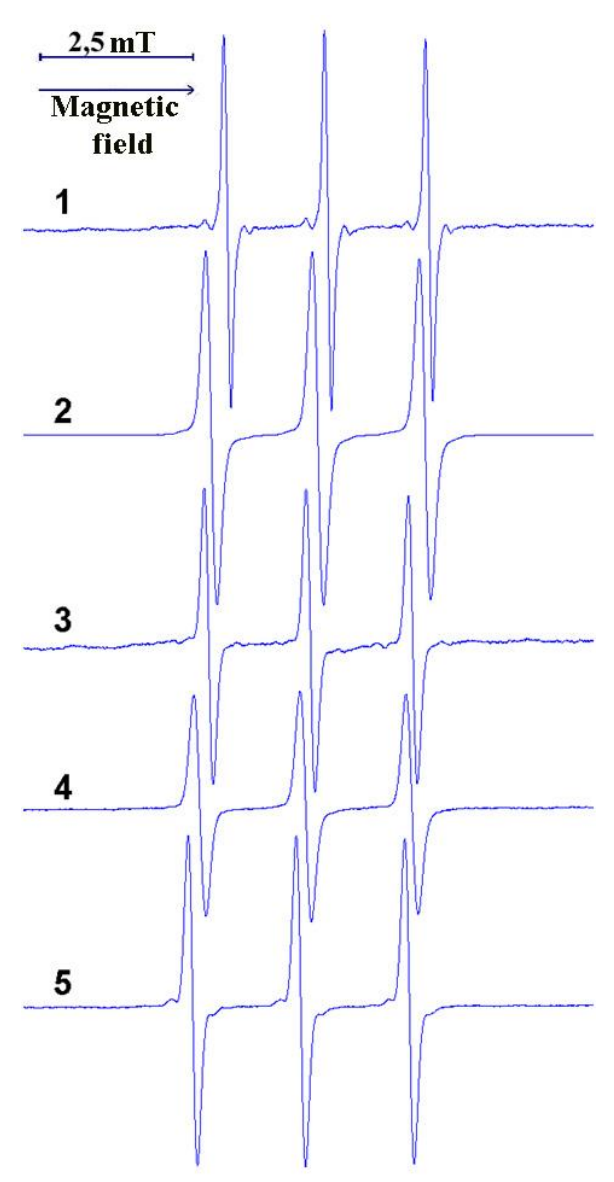

$a$

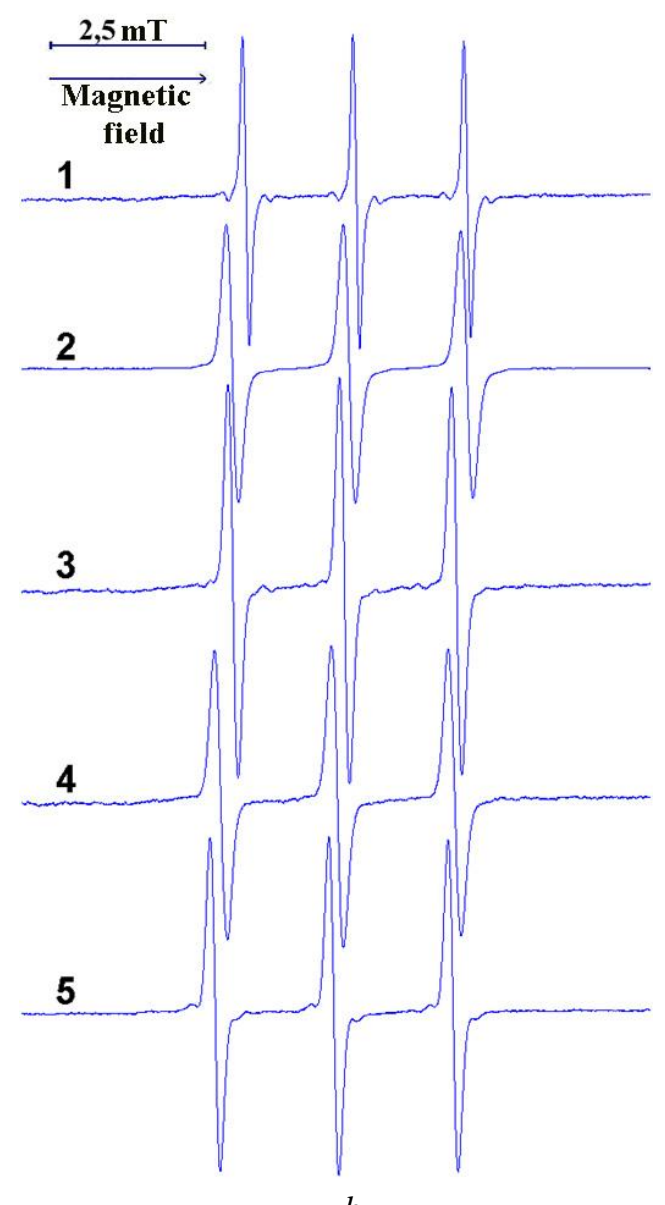

$b$

Fig. 3. EPR spectra of different spine probes: $a$-in water; $b$-in the gel containing $3.0 \%$ Walocel HM 4000 PA 2910. EPR spectra of the spine probe: 1 - TEMPON; 2 - TEMPOL; 3 - TEMPO; 4 -4-amino-TEMPO; 5 - PCA

Table 4

Apparent viscosity ( $\eta$ ) of the $3.0 \%$ gels based on different types of HPMC at $25{ }^{\circ} \mathrm{C}$ and $\mathrm{D}_{\mathrm{r}}=14.6 \mathrm{~s}^{-1}$ as well as $\tau_{-1}$ for spine probe TEMPON in these gels

\begin{tabular}{|c|c|c|}
\hline HPMC type & $\eta, \mathrm{Pa} \cdot \mathrm{s}$ & $\tau_{-1} \cdot 10^{11}, \mathrm{~s}$ \\
\hline Walocel HM 4000 PA 2910 & 6.63 & 0.82 \\
\hline Walocel HM 4000 PA 2906 & 7.35 & 0.89 \\
\hline Walocel HM 4000 PA 2208 & 6.39 & 1.01 \\
\hline Walocel HM 15000 PA 2208 & 13.08 & 0.80 \\
\hline Walocel HM 100000 PA 2208 & 31.36 & 0.83 \\
\hline
\end{tabular}

The apparent viscosity of the two gels based on Walocel HM 15000 PA 2208 and Walocel HM 100000 PA 2208 was significantly higher compared to other gels, but the values of $\tau_{-1}$ for the TEMPON probe in the gels are very similar (Table 4). That is, the type and molecular weight of the HPMC as well as the viscosity of the HPMC based gels did not affect the viscosity of the local surrounding of the spin probe molecules dissolved in the gels. The average value of $\tau_{-1}$ for spin probe TEMPON in gels with different types of HPMC at $25{ }^{\circ} \mathrm{C}$ was $(0.87 \pm 0.18) \cdot 10^{-11} \mathrm{~s}$, which differed from $\tau_{-1}$ of this spin probe in water within the determinate error (Table 3 and Table 4).

The same experiment was performed in regard to the liquids and gels containing DS and IPA (Table 1). The rheograms of the liquid No. 1 and gel No. 1 are illustrated in Fig. 4.

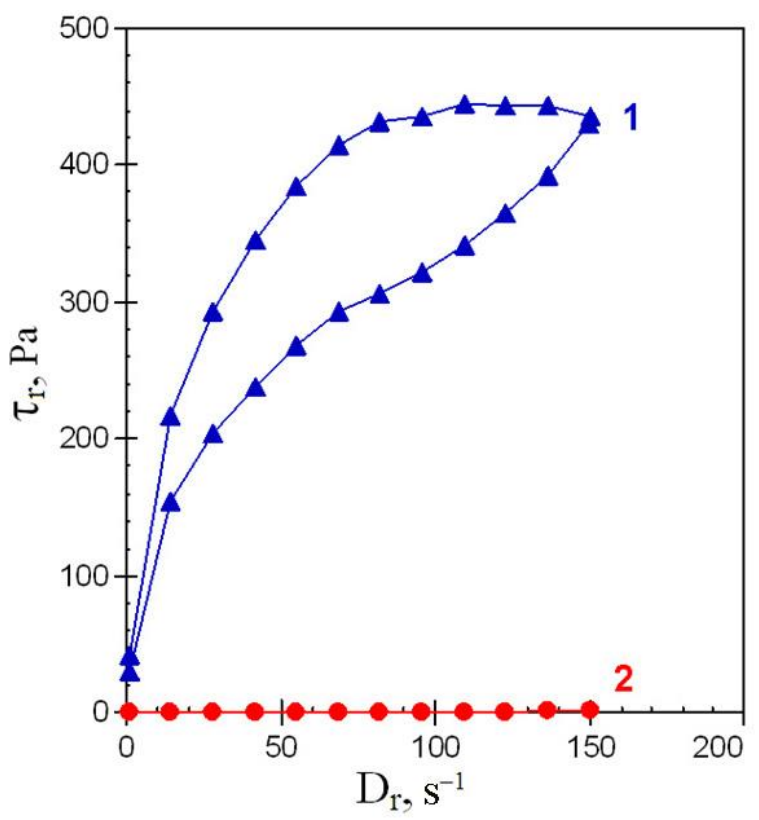

Fig. 4. Rheograms (at $25^{\circ} \mathrm{C}$ ) of the gel No. 1 (1) and the liquid No. 1 (2)

The liquid No. 1 was a Newtonian fluid (Fig. 4); its dynamic viscosity at $25^{\circ} \mathrm{C}$ was $5 \mathrm{mPa} \cdot \mathrm{s}$. On the rheogram of the gel No. 1 there was the yield value, which is inherent in fluids with the plastic flow; the gel No. 1 was 
characterized by pseudoplastic flow and thixotropic properties at shear rates up to $150 \mathrm{~s}^{-1}$ (Fig. 4). The apparent viscosity of the gel No. 1 at $\mathrm{Dr}=14.6 \mathrm{~s}^{-1}$ and at $25^{\circ} \mathrm{C}$ was $15 \mathrm{~Pa} \cdot \mathrm{s}$ and exceeded the dynamic viscosity of the liquid No. 1 by 3000 times.

The EPR spectra of the TEMPON probe in the liquids and gels are demonstrated in Fig. 5 and the parameters of these EPR spectra are presented in Table 5.

The EPR spectra and their parameters indicated that the molecules of the TEMPON probe were in a state of rapid isotropic rotation in a liquid medium both in the liquids No. 1 and No. 2 and in the gels No. 1 and No. 2 (Fig. 5, Table 5).

The polarity and viscosity of their local surrounding were identical in the respective liquids and gels.

That is, the TEMPON probe was in dissolved state in the mixed solvents water - IPA, and the gel formation did not affect the rotational correlation time $\left(\tau_{-1}\right)$ of its molecules in the gel compared to the solution.

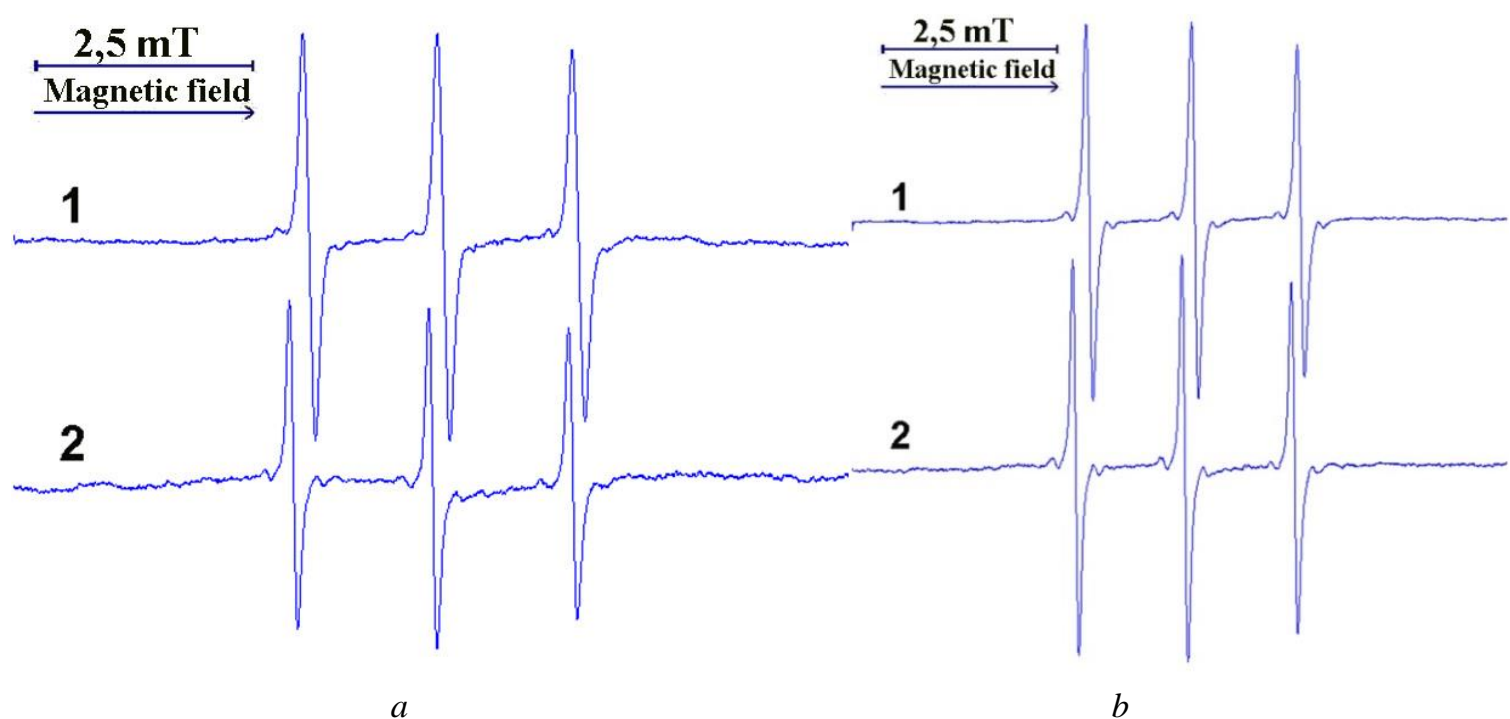

Fig. 5. EPR spectra of spine probe TEMPON in the liquids No. 1 i No. $2(a)$ and in the gels No. 1 i No. $2(b)$ at $25^{\circ} \mathrm{C}$

Table 5

Parameters of EPR spectra of spine probe TEMPON (Fig. 5) in the liquids and in the gels (Table 1) at $25{ }^{\circ} \mathrm{C}$

\begin{tabular}{|c|c|c|c|c|}
\hline Object & Spine probe & $\mathrm{A}_{\mathrm{N}}, \mathrm{mT}$ & $\tau_{-1} \cdot 10^{11}, \mathrm{~s}$ & Spectrum state \\
\hline Liquid No. 1 & TEMPON & 1.56 & 1.9 & triplet \\
\hline Gel No. 1 & TEMPON & 1.55 & 1.9 & triplet \\
\hline Liquid No. 2 & TEMPON & 1.58 & 2.2 & triplet \\
\hline Gel No. 2 & TEMPON & 1.58 & 2.0 & triplet \\
\hline
\end{tabular}

The same rotational correlation time of dissolved molecules in liquids and gels could be the prerequisite for their same in vitro release. It was rational to study the factors influencing the in vitro release of DS from liquids and gels. Appropriate analytical procedures was developed for the quantification of test substances in the receptor medium (DS and IPA), the validation results for which are summarized below.

Validation study of the analytical procedure for the assay of DS

The validation of the procedure for quantitative determination of DS was performed in the range of DS concentrations in model solutions from $24.15 \mu \mathrm{g} / \mathrm{ml}$ to $603.68 \mu \mathrm{g} / \mathrm{ml}$ (from $9.7 \%$ to $241.5 \%$ of the nominal concentration of DS in the reference solution $250 \mu \mathrm{g} / \mathrm{ml}$ ). This range was chosen taking into account the kinetics of DS content in the receptor medium during IVRT (6 hours).

Chromatograms of placebo solution, reference solution and model solutions are shown in Fig. 6.

The specificity of the analytical procedure was proven because on the chromatogram of the placebo solution there were no peaks with the retention time which coincided with the retention time of the diclofenac peak on the chromatograms of the reference solution and model solutions. The mean retention times of diclofenac peaks on the chromatograms of the reference solution and the model solution coincided with acceptable accuracy. The diclofenac peak was chromatographically pure.

Tab. 6 shows the results of the study of linearity, repeatability and accuracy in the range of DS concentrations from $10 \%$ to $250 \%$ of its nominal concentration in the reference solution $(250 \mu \mathrm{g} / \mathrm{ml})$. 


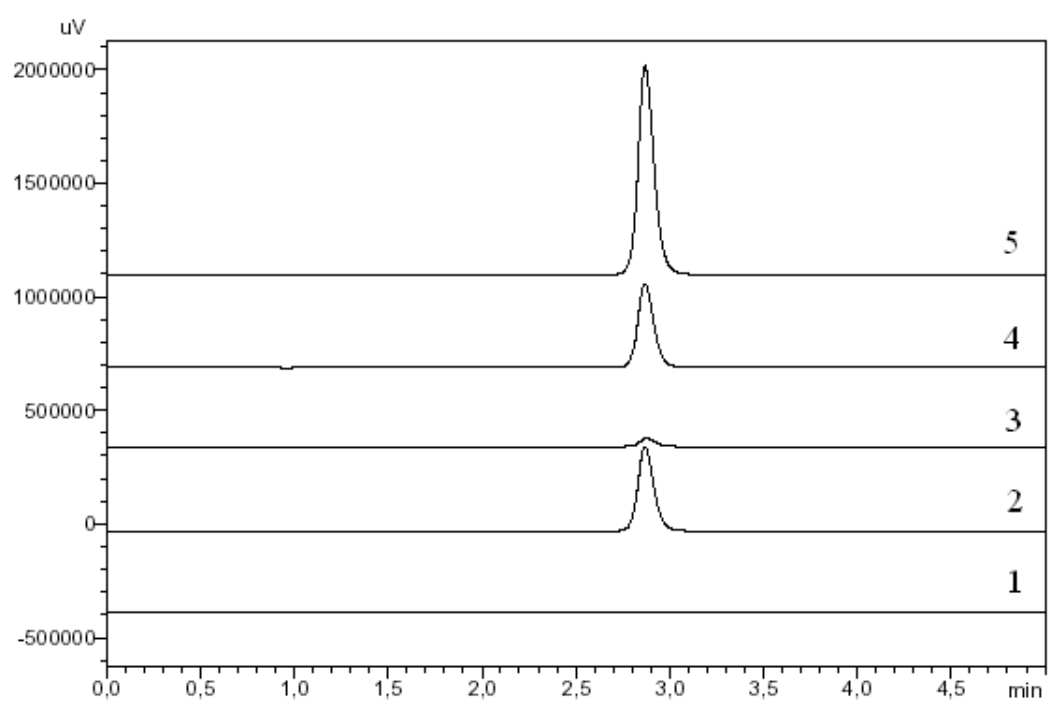

Fig. 6. Chromatograms of placebo solution (1), reference solution ( $250 \mu \mathrm{g} / \mathrm{ml})$ (2) and model solutions with DS concentrations $24.15 \mu \mathrm{g} / \mathrm{ml}$ (3), $241.47 \mu \mathrm{g} / \mathrm{ml}$ (4) and $603.68 \mu \mathrm{g} / \mathrm{ml}$ (5) obtained during the assay of DS (peaks with $\mathrm{Rt} \approx 2.8$ min correspond to diclofenac)

Table 6

Validation characteristics of the analytical procedure for DS assay by HPLC in the receptor medium and their evaluation against the acceptance criteria [25]

\begin{tabular}{|c|c|c|c|}
\hline Parameter & Value & Criteria $(n=11)$ & Conclusion \\
\hline \multicolumn{4}{|c|}{ Linearity } \\
\hline$b$ & 0.99388 & & \\
\hline$S_{b}$ & 0.00097 & & \\
\hline$\alpha$ & 0.26661 & $\begin{array}{l}\text { 1) }\left|S_{\alpha} \times 1.8331\right|=|0.23| \\
\text { 2) if it does not meet the criterion (1), then }|1.07|\end{array}$ & $\begin{array}{l}\text { Pass with criterion } \\
2\end{array}$ \\
\hline$S_{\alpha}$ & 0.12440 & & \\
\hline$S D_{\text {rest }}$ & 0.23031 & $|1.64|$ & Pass \\
\hline$r$ & 1,00000 & $\geq|0.99978|$ & Pass \\
\hline \multicolumn{4}{|c|}{ Repeatability } \\
\hline standard deviation $S D_{\Delta z i}, \%$ & 0.51 & & \\
\hline $\begin{array}{c}\text { confidence interval: } \\
\Delta_{\Delta Z i}=t(95 \%, 11-1) \times S D_{\Delta z i}\end{array}$ & 0.92 & $\leq 3.0 \%$ & Pass \\
\hline \multicolumn{4}{|c|}{ Accuracy } \\
\hline mean value $\Delta Z, \%$ & -0.38 & & \\
\hline 1) statistical insignificance $|\Delta Z|$ : & \multirow[t]{2}{*}{0.38} & $|\Delta Z| \leq \frac{t(95 \%, 11-1)}{\sqrt{11}} \times S D_{\Delta Z i}=0,28 \%$ & \multirow[t]{2}{*}{$\begin{array}{c}\text { Pass with criterion } \\
2\end{array}$} \\
\hline 2) practical insignificance $|\Delta Z|$ : & & $|\Delta Z| \leq 0.32 \times 3.0 \%=0.96 \%$ & \\
\hline
\end{tabular}

According to the results of validation studies, the procedure for the assay of DS in the receptor medium by HPLC in the specified range met the acceptance criteria for linearity, repeatability and accuracy (Table 6). The solutions were stable for at least 24 hours.

Based on the results of the linearity study (Table 6 ), the quantitation limit (QL) for DS in normalized coordinates was [25]:

$$
Q L=10 \times S_{\alpha}: b=10 \times 0.12440: 0,99388=1.25 \%
$$

Such QL for DS (1.25\% of the nominal concentration of DS in the reference solution) corresponded to DS concentration in the receptor medium $3.13 \mu \mathrm{g} / \mathrm{ml}$.

Validation study of the analytical procedure for the assay of IPA

The validation of the procedure for quantitative determination of IPA was performed in the range of IPA concentrations in model solutions from $1.07 \mathrm{mg} / \mathrm{ml}$ to $24.00 \mathrm{mg} / \mathrm{ml}$ (from $10.7 \%$ to $240.0 \%$ of the nominal concentration of IPA in the reference solution $10 \mathrm{mg} / \mathrm{ml})$.

Fig. 7 shows the chromatograms of solvent (blank), reference solution and test solutions.

The specificity of the analytical procedure was validated because on the chromatogram of the solvent (blank) there were no peaks with the retention time which coincided with the retention time of the IPA peak on the chromatograms of the reference solution and test solutions. In addition, there was no difference in the retention times of the IRA peaks on the chromatograms of the test solutions and reference solution.

The results of the validation of the procedure for IPA assay by GC in regard to linearity, repeatability and accuracy as well as their evaluation against acceptance criteria are provided in Table 7. 


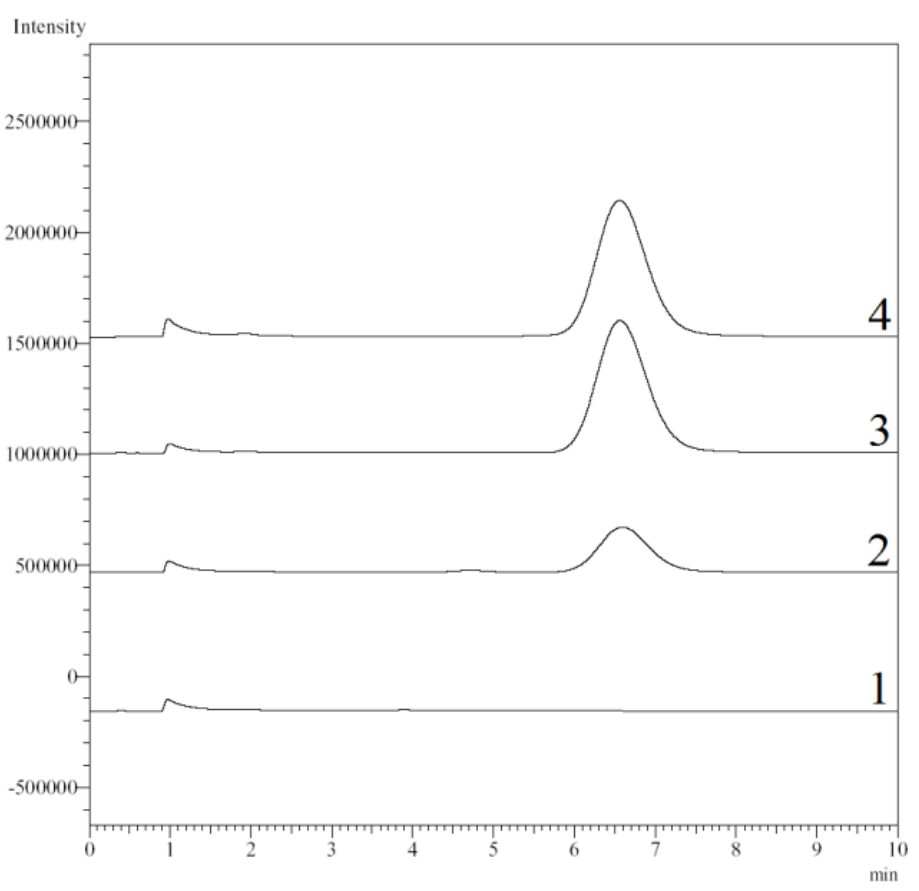

Fig. 7. Chromatograms of solvent (blank) (1), test solution with the lowest IPA concentration (release time point $30 \mathrm{~min}$ ) (2), test solution with the highest IPA concentration (release time point -6 hours) (3) and reference solution $(\sim 10 \mathrm{mg} / \mathrm{ml})$ (4) obtained during the assay of IPA (peaks with $\mathrm{Rt} \approx 6.5 \mathrm{~min}$ correspond to IPA)

Table 7

Validation characteristics of the analytical procedure for the IPA assay by GC in the receptor medium and their evaluation against the acceptance criteria [25]

\begin{tabular}{|c|c|c|c|}
\hline Parameter & Value & Criterion $(n=9)$ & Conclusion \\
\hline \multicolumn{4}{|c|}{ Linearity } \\
\hline$b$ & 0.99921 & & \\
\hline$S_{b}$ & 0.00512 & & \\
\hline$\alpha$ & 0.06584 & $\begin{array}{l}\text { 1) }\left|S_{\alpha} \times 1.8946\right|=|1.47| \\
\text { 2) if it does not meet the criterion (1), then }|1.07|\end{array}$ & Pass \\
\hline$S_{\alpha}$ & 0.77851 & & \\
\hline$S D_{\text {rest }}$ & 1.17498 & $|1.58|$ & Pass \\
\hline$r$ & 0.99991 & $\geq|0.99980|$ & Pass \\
\hline \multicolumn{4}{|c|}{ Repeatability } \\
\hline standard deviation $S D_{\Delta z i}, \%$ & 1.10 & & \\
\hline $\begin{array}{c}\text { confidence interval: } \\
\Delta_{\Delta Z i}=t(95 \%, 9-1) \times S D_{\Delta z i}\end{array}$ & 2.04 & $\leq 3.0 \%$ & Pass \\
\hline \multicolumn{4}{|c|}{ Accuracy } \\
\hline mean value $\Delta Z, \%$ & -0.04 & & \\
\hline 1) statistical insignificance $|\Delta Z|$ : & \multirow[t]{2}{*}{0.04} & $|\Delta Z| \leq \frac{t(95 \%, 9-1)}{\sqrt{9}} \times S D_{\Delta Z i}=0,68 \%$ & \multirow[t]{2}{*}{ Pass } \\
\hline 2) practical insignificance $|\Delta Z|$ : & & $|\Delta Z| \leq 0.32 \times 3.0 \%=0.96 \%$ & \\
\hline
\end{tabular}

According to the data presented in Table 7, the procedure for quantitative determination of IRA by GC in the receptor medium met the acceptance criteria for linearity, repeatability and accuracy established by State Pharmacopoeia of Ukraine [24]. The solutions were stable for more than 24 hours.

QL for IPA in normalized coordinates was:

$$
Q L=10 \times 0.77851: 0.99921=7.79 \%
$$

Such QL for IPA (7.79 \% of nominal content of IPA in the reference solution) corresponded to IPA concentration in the receptor medium $0.78 \mathrm{mg} / \mathrm{ml}$.

\section{IVRT validation}

Membrane inertness. The inertness of cellulose membrane was studied by immersing each of three membranes into $60 \mathrm{ml}$ of identical test solutions of DS in water $R(502.4 \mu \mathrm{g} / \mathrm{ml})$. Three test solutions and three control solutions (the same solutions without immersed membranes) were kept at $(32 \pm 0.5){ }^{\circ} \mathrm{C}$ for 6 hours. Subsequently, the DS concentration in all six solutions was determined and recovery was calculated by dividing the mean DS concentration in the test solutions by the mean DS concentration in the control solutions. The recovery was $97.81 \%$ (SD: $0.45 \%$ ) while the acceptance criterion was $\geq 95 \%$. Thus, DS did not interact with cellulose 
membrane and the membrane did not present a rate limiting barrier for the diffusion of DS.

Solubility of DS in the receptor medium (water $R$ ). In order to determine the solubility excessive amount of DS was added to water $R$ and mixture was kept at $(32 \pm 0.5){ }^{\circ} \mathrm{C}$ for $6 \mathrm{~h}$ with stirring and then was allowed to remain at the same temperature for $24 \mathrm{~h}$ without stirring. Such experiment was performed in triplicate. After that aliquots of supernatant were withdrawn, filtered (syringe filter, $0.2 \mu \mathrm{m})$ and concentration of dissolved DS was determined. The concentration of DS in its saturated solution was $26.44 \mathrm{mg} / \mathrm{ml}$ (SD: $0.16 \mathrm{mg} / \mathrm{ml}$ ), which was 39.5 times higher than the highest concentration $(0.67 \mathrm{mg} / \mathrm{ml})$ in the samples obtained during IVRT validation (acceptance criterion $>10$ times higher than the maximum DS concentration in the receptor medium during IVRT).

Linearity, precision and reproducibility. Fig. 8 shows the mean release rates (the released amount of DS per unit area of the membrane versus the square root of time) for three IVRT runs using gel No. 1 with DS content of $5.0 \%$. The relevant release parameters are given in Table 8.

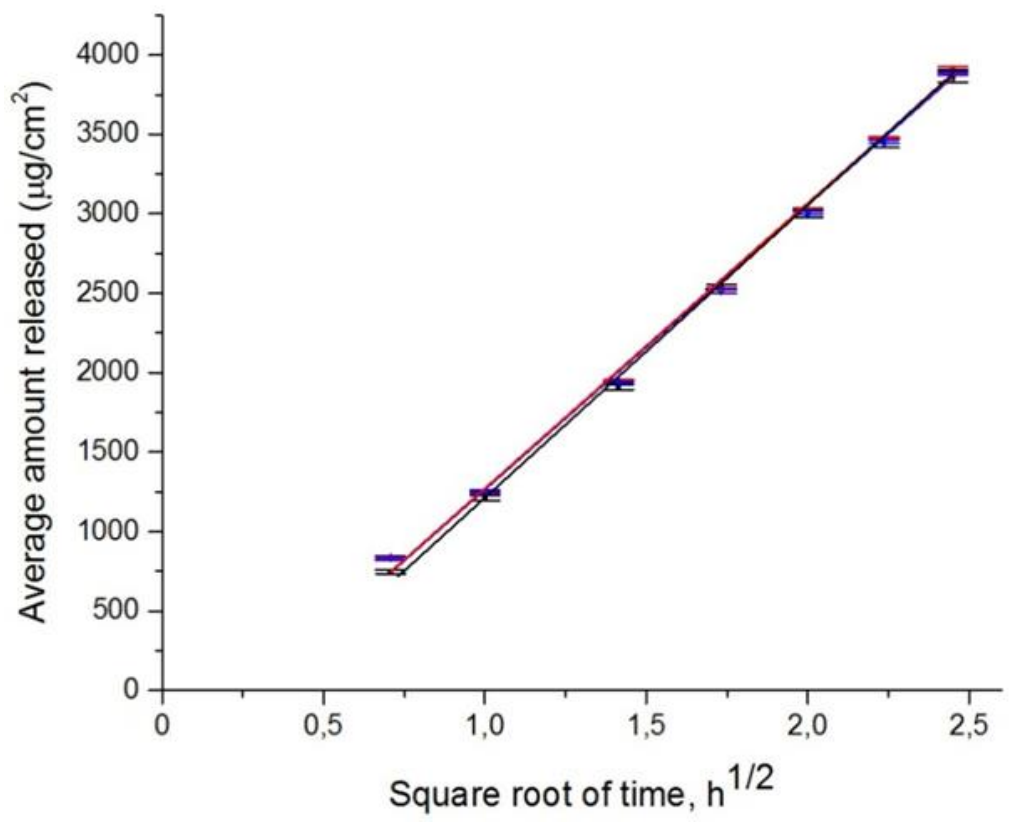

Fig. 8. Release rate plots obtained from the three IVRT runs using gel No. 1

Table 8

Parameters of DS release from the gel No. 1 for three IVRT runs

\begin{tabular}{|c|c|c|c|}
\hline \multirow{2}{*}{ Parameter } & \multicolumn{3}{|c|}{ Results } \\
\hline & Run 1 & Run 2 & Run 3 \\
\hline Release rate $(R), \mu \mathrm{g} / \mathrm{cm}^{2} / \mathrm{h}^{-1 / 2}$ & $\begin{array}{l}1797.92 \pm 41.72 \\
\text { SD: } 20.71\end{array}$ & $\begin{array}{l}1774.22 \pm 22.19 \\
\text { SD: } 11.01\end{array}$ & $\begin{array}{l}1755.96 \pm 21.08 \\
\text { SD: } 10.46\end{array}$ \\
\hline $\begin{array}{l}\text { Cumulative amount }(\mathrm{A}) \\
\text { (at the time point } 6 \mathrm{~h}), \mu \mathrm{g} / \mathrm{cm}^{2}\end{array}$ & $\begin{array}{c}3865.75 \pm 79.28 \\
\text { SD: } 39.35 \\
\end{array}$ & $\begin{array}{c}3907.51 \pm 33.82 \\
\text { SD: } 16.78 \\
\end{array}$ & $\begin{array}{c}3882.97 \pm 24.20 \\
\text { SD: } 12.01 \\
\end{array}$ \\
\hline $\begin{array}{l}\text { DS content }(\mathrm{C}) \text { in the receptor medium } \\
\text { (at the time point } 6 \mathrm{~h}), \mu \mathrm{g} / \mathrm{ml}\end{array}$ & $\begin{array}{l}455 \pm 9.34 \\
\text { SD: } 4.63\end{array}$ & $\begin{array}{l}460.11 \pm 3.98 \\
\text { SD: } 1.98\end{array}$ & $\begin{array}{l}457.22 \pm 2.85 \\
\text { SD: } 1.41\end{array}$ \\
\hline Correlation coefficient $r$ & $\begin{array}{l}0.99945 \pm 0.00030 \\
\text { SD: } 0.00015\end{array}$ & $\begin{array}{l}0.99893 \pm 0.00035 \\
\text { SD: } 0.00017\end{array}$ & $\begin{array}{l}0.99892 \pm 0.00025 \\
\text { SD: } 0.00013\end{array}$ \\
\hline Coefficient of determination $\mathrm{R}^{2}$ & 0.999 & 0.998 & 0.998 \\
\hline Recovery (at the time point $6 \mathrm{~h}$ ), $\%$ & $\begin{array}{l}18.21 \pm 0.37 \\
\text { SD: } 0.19\end{array}$ & $\begin{array}{l}18.40 \pm 0.16 \\
\text { SD: } 0.08\end{array}$ & $\begin{array}{l}18.29 \pm 0.11 \\
\text { SD: } 0,06\end{array}$ \\
\hline
\end{tabular}

According to the presented plots and values of correlation coefficients (Fig. 8, Table 8) the relationship between DS amount released per unit area of the membrane versus the square root of time was linear for all of three IVRT runs. Coefficients of determination were greater than 0.99 (acceptance criterion $\mathrm{R}^{2}>0.90$ ).

The maximum relative standard deviation for the release rate in the individual IVRT run $\left(\mathrm{RSD}_{\text {intra-run }}\right)$ did not exceed $1.15 \%$, and the maximum relative standard deviation for the release rate between IVRT runs
$\left(\mathrm{RSD}_{\text {inter-run }}\right)$ did not exceed $1.27 \%$. These results met the acceptance criteria of USP (RSD $<15 \%$ ) and EMA (RSD $<10 \%)$ and confirmed the precision and reproducibility of the IVRT procedure.

Sensitivity, specificity and selectivity. Fig. 9 shows the mean release rates (the released amount of DS per unit area of the membrane versus the square root of time) for three IVRT runs using gels with different content of DS: $2.5 \%, 5.0 \%$ and $7.5 \%$. The relevant release parameters are given in Table 9. 


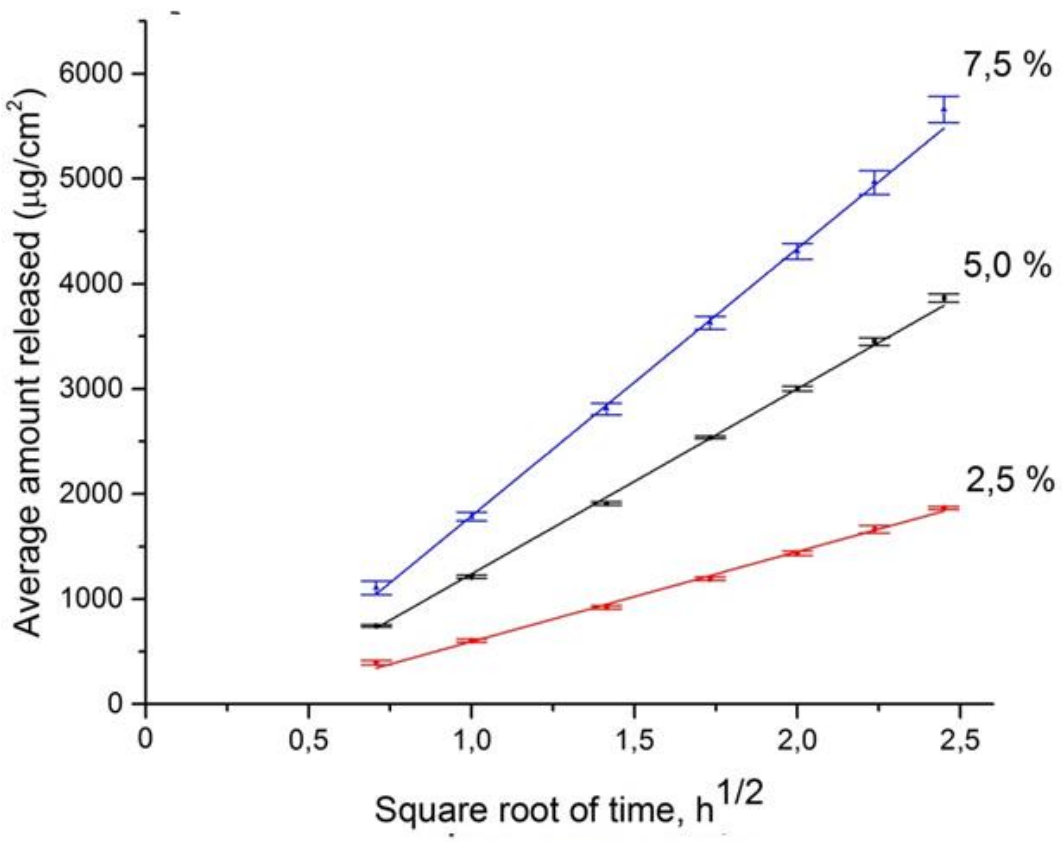

Fig. 9. Release rate plots obtained from the IVRT runs using gels with different content of DS: $2.5 \%, 5.0 \%$ and $7.5 \%$

Table 9

Parameters of DS release from the gels with different content of the active substance

\begin{tabular}{|l|c|c|c|}
\hline \multirow{2}{*}{ Parameter } & \multicolumn{3}{|c|}{ Results } \\
\cline { 2 - 4 } & $5.0 \%$ gel & $2.5 \%$ gel & $7.5 \%$ gel \\
\hline \multirow{2}{*}{ Release rate $(R), \mu \mathrm{g} / \mathrm{cm}^{2} / \mathrm{h}^{-1 / 2}$} & $1797.92 \pm 41.72$ & $846.15 \pm 40.38$ & $2585.37 \pm 166.41$ \\
& SD: 20.71 & SD: 20.04 & SD: 82.58 \\
\hline Cumulative amount $(\mathrm{A})$ & $3865.75 \pm 79.28$ & $1864.90 \pm 29.07$ & $5657.91 \pm 251.42$ \\
(at the time point $6 \mathrm{~h}), \mu \mathrm{g} / \mathrm{cm}^{2}$ & SD: 39.35 & SD: 14.43 & SD: 124.77 \\
\hline $\mathrm{A}_{2,5 \% / 7,5 \%} / \mathrm{A}_{5} \% \%$ & & $47.74-48.73$ & $144.18-148.55$ \\
\hline$R_{2,5 \% / 7,5 \%} / R_{5} \%$ & & $46.15-47.88$ & $139.53-148.50$ \\
\hline DS content $(\mathrm{C})$ in the receptor medium & $455 \pm 9.34$ & $219.59 \pm 3.42$ & $666.22 \pm 29.60$ \\
$($ at the time point $6 \mathrm{~h}), \mu \mathrm{g} / \mathrm{ml}$ & SD: 4.63 & SD: 1.70 & SD: 14.69 \\
\hline \multirow{2}{*}{ Correlation coefficient $\mathrm{r}$} & $0.99945 \pm 0.00030$ & $0.99814 \pm 0.00163$ & $0.99865 \pm 0.00230$ \\
& SD: 0.00015 & SD: 0.00081 & SD: 0.00114 \\
\hline Coefficient of determination $\mathrm{R}^{2}$ & 0.999 & 0.996 & 0.997 \\
\hline \multirow{2}{*}{ Recovery (at the time point $6 \mathrm{~h}), \%$} & $18.21 \pm 0.37$ & $16.83 \pm 0.26$ & $17.81 \pm 0.79$ \\
\end{tabular}

The mean DS release rate was lower for the $2.5 \%$ gel compared to $5.0 \%$ gel, and the mean DS release rate was higher for the $7.5 \%$ gel compared to $5.0 \%$ gel $\left(846.15 \mu \mathrm{g} / \mathrm{cm}^{2} / \mathrm{h}^{-1 / 2}<1797.92 \mu \mathrm{g} / \mathrm{cm}^{2} / \mathrm{h}^{-1 / 2}<\mu \mathrm{g} / \mathrm{cm}^{2} / \mathrm{h}^{-1 / 2}\right)$ (Table 9), so the IVRT procedure was considered to be sensitive.

Fig. 10 shows the evidence of linear, proportional relationship between the DS concentration in the gels and respective release rates; the coefficient of determination $\mathrm{R}^{2}$ was 0.997 (acceptance criterion $>0.90$ ). Thus, the specificity of the IVRT procedure was confirmed.

The selectivity of the IVRT procedure (the ability to discriminate the non-equivalent characteristics in the case of product with different content of DS: $2.5 \%$, $5.0 \%$ and $7.5 \%$ ) was evaluated by assessing the ratio of
DS release rates from $2.5 \%$ and $7.5 \%$ gels and DS release rates from $5.0 \%$ gel.

The values of the ratio in case of comparison of the DS release rates for $2.5 \%$ gel DS and $5.0 \%$ gel were in the range of $46.15-47.88 \%$, and if the release rates for $7.5 \%$ gel have been compared with the same parameter for $5.0 \%$ gel the ratios were from $139.53 \%$ to $148.50 \%$.

In both case the ratios $R_{2.5 \%} / R_{5.0 \%}$ and $R_{7.5 \%} / R_{5.0 \%}$, converted to percent, were outside the limits of $75.00 \%$ and $133.33 \%$ (USP criterion). In addition, all values were out of the range of $90-111 \%$, that is, the EMA criterion was also met. So, the IVRT procedure was considered to be selective in regard to its ability to accurately discriminate the different release rates in the case of non-equivalent products. 


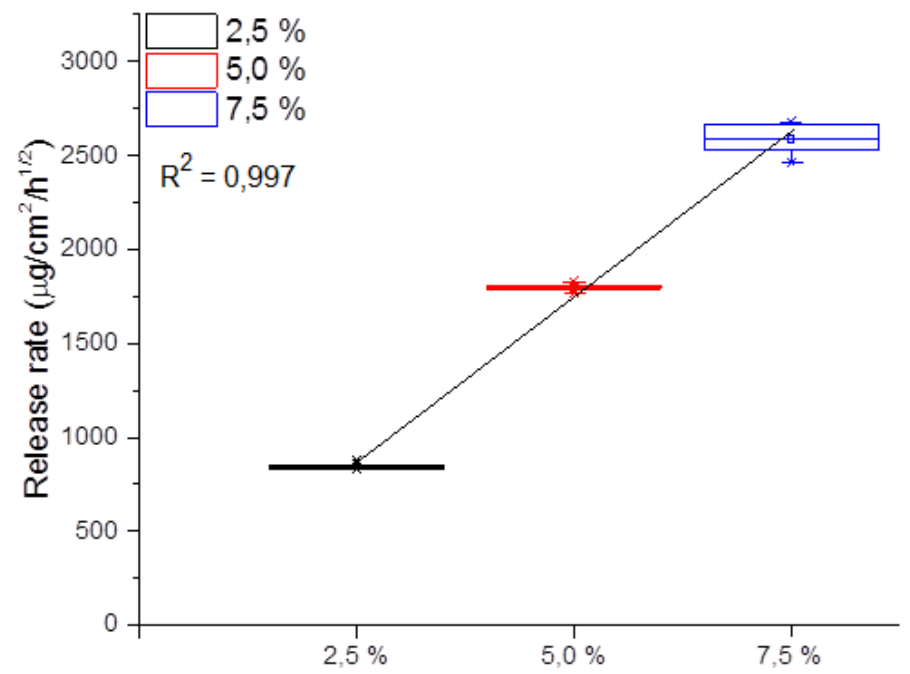

Fig. 10. Box and whiskers plot of the released rates for three gels with different content of DS

To verify the ability of the IVRT procedure to accurately identify equivalent product performance the pairwise comparison were performed using the results of three IVRT runs with $5.0 \%$ gel (Table 8). The results indicate that the computed limits for all pairwise comparisons were within the range of 75.00-133.33\% (USP criterion) and even in the range of 90-111\% (EMA criterion): run 1 vs run $2-97.55-99.83 \%$; run 1 vs run $3-$
96.86-98,62\% and run 2 vs run $3-98.31-99,54 \%$. The results confirmed the ability of IVRT procedure to accurately detect the equivalent product performance.

Robustness in regard to minor variations in temperature. Fig. 11 shows the results obtained in three IVRT runs at different temperatures $\left(30{ }^{\circ} \mathrm{C}, 32{ }^{\circ} \mathrm{C}\right.$ and $34{ }^{\circ} \mathrm{C}$ ) using gel No. 1; the relevant release parameters are given in Table 10 .

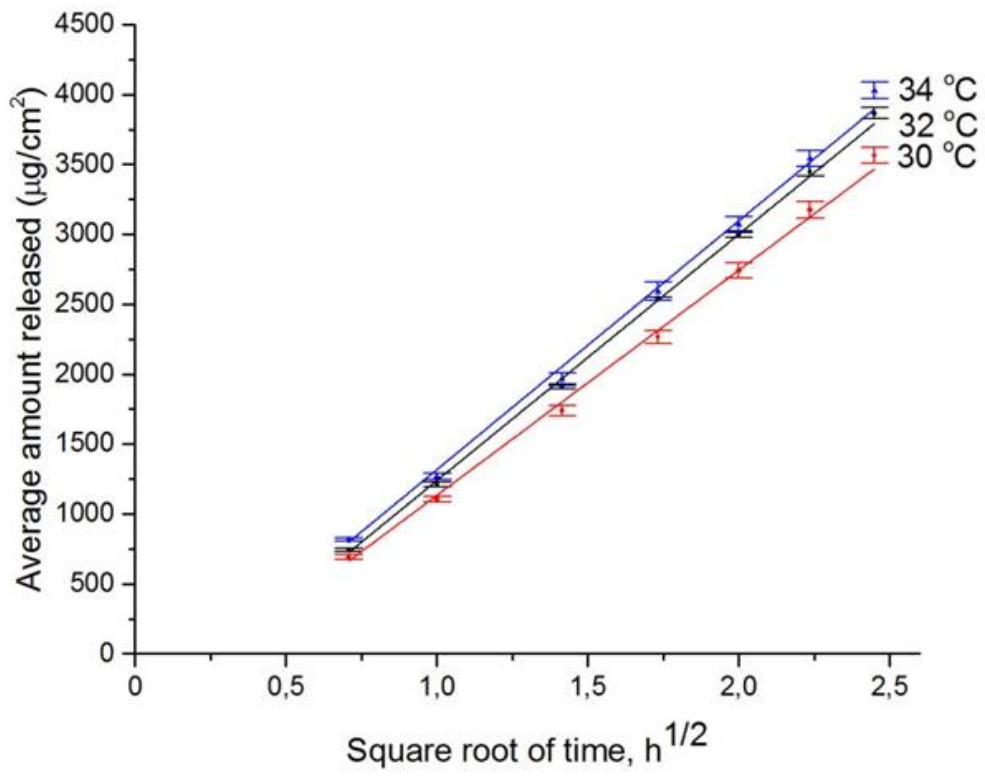

Fig. 11. Release rate plots obtained from the three IVRT runs performed at different temperatures

Table 10

Parameters of DS release from the gel No. 1 at different temperatures

\begin{tabular}{|l|c|c|c|}
\hline \multirow{2}{*}{ Parameter } & \multicolumn{3}{|c|}{ Results at temperature of: } \\
\cline { 2 - 4 } & $32^{\circ} \mathrm{C}$ & $30{ }^{\circ} \mathrm{C}$ & $34{ }^{\circ} \mathrm{C}$ \\
\hline Release rate $(R), \mu \mathrm{g} / \mathrm{cm}^{2} / \mathrm{h}^{-1 / 2}$ & $1797.92 \pm 41.72$ & $1651.13 \pm 59.36$ & $1837.14 \pm 56.23$ \\
& SD: 20.71 & SD: 29.46 & SD: 27.90 \\
\hline Cumulative amount $(\mathrm{A})$ & $3865.75 \pm 79.28$ & $3566.20 \pm 114.60$ & $4029.10 \pm 120.04$ \\
$($ at the time point $6 \mathrm{~h}), \mu \mathrm{g} / \mathrm{cm}^{2}$ & SD: 39.35 & SD: 56.87 & SD: 59.57 \\
\hline $\mathrm{A}_{30 / 34} / \mathrm{A}_{32}, \%$ & & $90.83-93.87$ & $102.56-105.70$ \\
\hline$R_{30 / 34} / R_{32}, \%$ & & $90.21-93.44$ & $100.60-104.15$ \\
\hline Coefficient of determination $\mathrm{R}^{2}$ & 0.999 & 0.998 & 0.997 \\
\hline
\end{tabular}


According to the presented data (Fig. 11, Table 10) the mean release rates obtained in IVRT runs at different temperature (i.e. $32{ }^{\circ} \mathrm{C}$ and $34{ }^{\circ} \mathrm{C}$ ) did not deviate by more than $15 \%$ (acceptance criterion) from the mean release rates obtained in IVRT runs at nominal temperature $32{ }^{\circ} \mathrm{C}$. These results confirmed that the IVRT procedure was robust in regard to minor temperature changes.

Recovery. This parameter characterizes the extent of dose depletion during the IVRT. Regarding gel No. 1 the recovery (and corresponding dose depletion) was
$18.21 \%$ after 6-hour experiment. Since this value did not exceed USP acceptance criterion $(30 \%)$ the extent of dose depletion was considered to be acceptable.

\section{liquids}

\section{Study of release of DS and IPA from gels and}

Fig. 12 shows the DS release rate in the case of the gel No. 1 and liquid No. 1, both of which contained $5.0 \%$ of DS and $45.0 \%$ of IPA; the relevant release parameters are presented in Table 11.

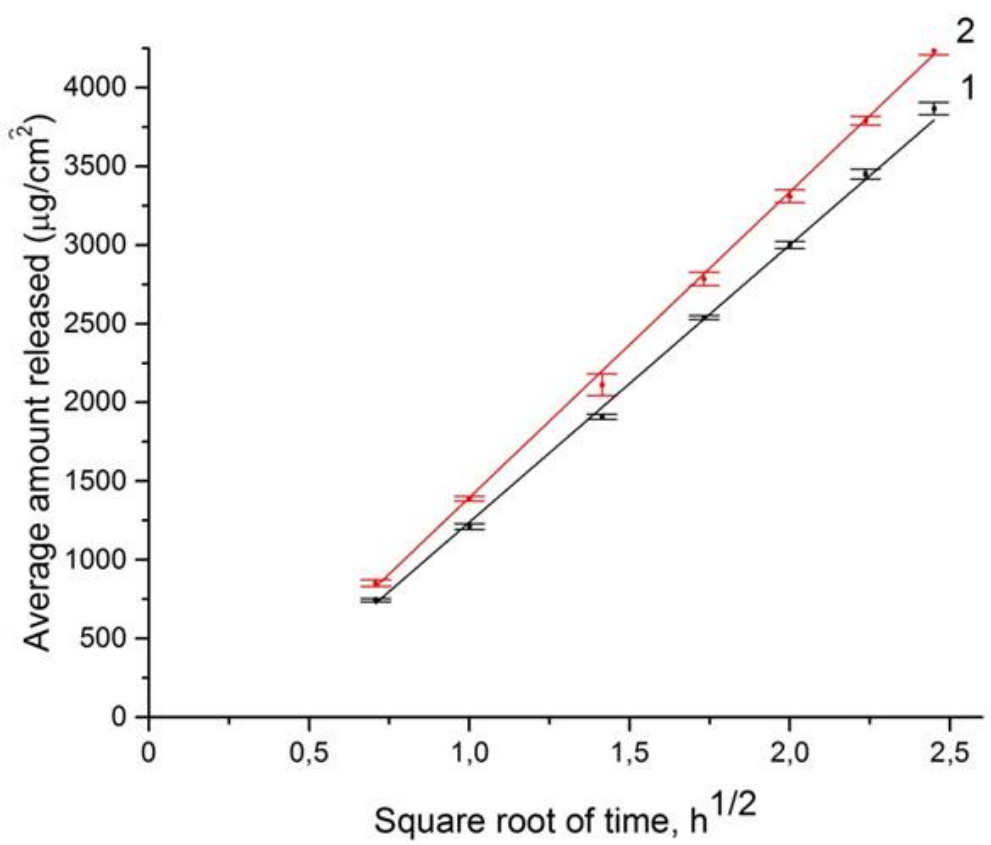

Fig. 12. Release rate plots for the gel No. 1 and liquid No. 1

As evidenced by the presented data (Fig. 12, Table 11) the relationship between the released amount of DS per unit area of the membrane and the square root of time was linear for both gel No. 1 and liquid No. 1. The mean release rate $(\mathrm{R})$ of DS from liquid No. 1 compared to gel No. 1 was greater by $8.1 \%$, and the DS content in the receptor medium $(\mathrm{C})$, the cumulative amount of DS released (A) and the DS recovery were higher by $9.5 \%$. The ratios $\mathrm{A}_{\text {liquid }} / \mathrm{A}_{\text {gel }}$ were within the range of
108.63-109.97 \%, and the ratios $\mathrm{R}_{\text {liquid }} / \mathrm{R}_{\text {gel }}$ were within the range of 106.99-109.20\%, i.e. they remained within the limits 90-111\%. Taking into account these strict criteria the gel No. 1 and liquid No. 1 could be considered equivalent in regard to release of DS.

That is, the presence of HPMC in gel and significant differences in the flow behaviour and viscosity of the test samples had very little effect on the parameters of DS release.

Table 11

Parameters of DS release from the gel No. 1 and the liquid No. 1

\begin{tabular}{|c|c|c|}
\hline \multirow[t]{2}{*}{ Parameter } & \multicolumn{2}{|c|}{ Results } \\
\hline & Gel No. 1 & Liquid No. 1 \\
\hline Release rate $(R), \mu \mathrm{g} / \mathrm{cm}^{2} / \mathrm{h}^{-1 / 2}$ & $\begin{array}{c}1797.92 \pm 41.72 \\
\text { SD: } 20.71\end{array}$ & $\begin{array}{l}1943.48 \pm 20.50 \\
\text { SD: } 10.17\end{array}$ \\
\hline Cumulative amount (A) (at the time point $6 \mathrm{~h}$ ), $\mu \mathrm{g} / \mathrm{cm}^{2}$ & $\begin{array}{c}3865.75 \pm 79.28 \\
\text { SD: } 39.35\end{array}$ & $\begin{array}{c}4233.27 \pm 45.95 \\
\text { SD: } 22.80\end{array}$ \\
\hline$A_{\text {liquid }} / A_{\text {gel }}, \%$ & & 108.63-109.97 \\
\hline$R_{\text {liquid }} / R_{\text {gel }}, \%$ & & $106.99-109.20$ \\
\hline DS content $(\mathrm{C})$ in the receptor medium (at the time point $6 \mathrm{~h}$ ), $\mu \mathrm{g} / \mathrm{ml}$ & $\begin{array}{c}455.00 \pm 9.34 \\
\text { SD: } 4.63\end{array}$ & $\begin{array}{c}498.47 \pm 5.41 \\
\text { SD: } 2.69\end{array}$ \\
\hline Correlation coefficient $r$ & $\begin{array}{c}0.99945 \pm 0.00030 \\
\text { SD: } 0.00015\end{array}$ & $\begin{array}{c}0.99934 \pm 0.00143 \\
\text { SD: } 0.00071\end{array}$ \\
\hline Coefficient of determination $\mathrm{R}^{2}$ & 0.999 & 0.999 \\
\hline Recovery (at the time point $6 \mathrm{~h}$ ), $\%$ & $\begin{array}{c}18.21 \pm 0.37 \\
\text { SD: } 0.19\end{array}$ & $\begin{array}{l}19.94 \pm 0.22 \\
\text { SD: } 0.11\end{array}$ \\
\hline
\end{tabular}


The results of the IVRT tests using medicinal products Diclac ${ }^{\circledR}$ gel $5 \%$, Diclofenac gel $5 \%$ and the gel No. 1 are illustrated in Fig. 13; Table 12 shows the relevant release parameters.

The products are different in respect to their microstructure (Fig. 1). In the product Diclac ${ }^{\circledR}$ gel $5 \%$ and in the gel No. 1 DS is in dissolved state in the mixed solvent water - IPA. As shown by the microphotograph (Fig. 1,b) Diclofenac gel $5 \%$ contains numerous crystals of DS which contact with a saturated solution of DS in the mixed solvent water - ethanol - DMSO - macrogol 400 - glycerin [11].

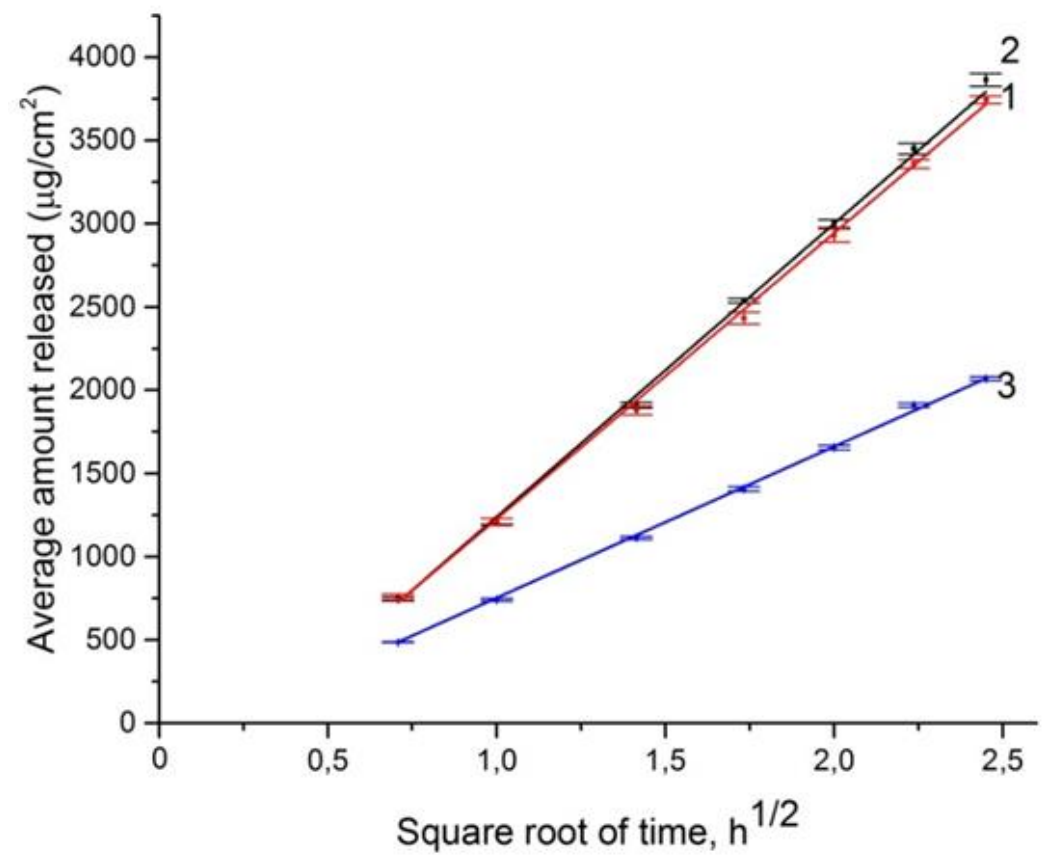

Fig. 13. Release rate plots for Diclac ${ }^{\circledR}$ gel $5 \%$ (1), the gel No. 1 (2) and Diclofenac gel $5 \%$ (3)

Table 12

Parameters of DS release from Diclac ${ }^{\circledR}$ gel $5 \%(\mathbf{R})$, the gel No. $1\left(\mathbf{T}_{\mathbf{1}}\right)$ and Diclofenac gel $5 \%\left(\mathbf{T}_{\mathbf{2}}\right)$

\begin{tabular}{|c|c|c|c|}
\hline \multirow{2}{*}{ Parameter } & \multicolumn{3}{|c|}{ Results } \\
\hline & $\mathbf{R}$ & $\mathbf{T}_{1}$ & $\mathbf{T}_{2}$ \\
\hline Release rate $(R), \mu \mathrm{g} / \mathrm{cm}^{2} / \mathrm{h}^{-1 / 2}$ & $\begin{array}{l}1723.78 \pm 22.48 \\
\text { SD: } 11.16\end{array}$ & $\begin{array}{l}1797.92 \pm 41.72 \\
\text { SD: } 20.71\end{array}$ & $\begin{array}{l}920.09 \pm 16.24 \\
\text { SD: } 8.06\end{array}$ \\
\hline $\begin{array}{l}\text { Cumulative amount (A) } \\
\text { (at the time point } 6 \mathrm{~h}), \mu \mathrm{g} / \mathrm{cm}^{2}\end{array}$ & $\begin{array}{l}3745.97 \pm 39.16 \\
\text { SD: } 19.44\end{array}$ & $\begin{array}{l}3865.75 \pm 79.28 \\
\text { SD: } 39.35\end{array}$ & $\begin{array}{l}2068.69 \pm 24.23 \\
\text { SD: } 12.02\end{array}$ \\
\hline $\mathrm{A}_{\mathrm{T}} / \mathrm{A}_{\mathrm{R}}, \%$ & & $102.91-103.84$ & $54.89-55.62$ \\
\hline$R_{\mathrm{T}} / R_{\mathrm{R}}, \%$ & & $103.30-105.31$ & $52.86-53.85$ \\
\hline $\begin{array}{l}\text { DS content }(\mathrm{C}) \text { in the receptor medium } \\
\text { (at the time point } 6 \mathrm{~h}), \mu \mathrm{g} / \mathrm{ml}\end{array}$ & $\begin{array}{l}441.09 \pm 4.61 \\
\text { SD: } 2.29\end{array}$ & $\begin{array}{l}455.00 \pm 9.34 \\
\text { SD: } 4.63\end{array}$ & $\begin{array}{l}243.59 \pm 2.85 \\
\text { SD: } 1.42\end{array}$ \\
\hline Correlation coefficient $\mathrm{r}$ & $\begin{array}{l}0.99933 \pm 0.00050 \\
\text { SD: } 0.00025\end{array}$ & $\begin{array}{l}0.99945 \pm 0.00030 \\
\text { SD: } 0.00015\end{array}$ & $\begin{array}{l}0.99961 \pm 0.00027 \\
\text { SD: } 0.00014\end{array}$ \\
\hline Coefficient of determination $\mathrm{R}^{2}$ & 0.999 & 0.999 & 0.999 \\
\hline $\begin{array}{l}\text { Recovery } \\
\text { (at the time point } 6 \mathrm{~h} \text { ), \% }\end{array}$ & $\begin{array}{c}17.64 \\
\text { SD: } 0.09\end{array}$ & $\begin{array}{c}18.21 \\
\text { SD: } 0.19\end{array}$ & $\begin{array}{c}9.74 \\
\text { SD: } 0.06\end{array}$ \\
\hline
\end{tabular}

According to the USP and EMA acceptance criteria the gel No. $1\left(\mathrm{~T}_{1}\right)$ and Diclac $^{\circledR}$ gel $5 \%(\mathrm{R})$ are equivalent in regard to parameters of in vitro release of DS that can be explained by their identical formulations and microstructure. The mean release rate in the case of Diclofenac gel $5 \%\left(\mathrm{~T}_{2}\right)$ compared to reference product (R) was $53.38 \%$ and did not fall within ranges 75.00-133.33\% (criterion USP) and 90-111 \% (criterion EMA). That is, in regard to DS release rate, cumulative amount of DS in the receptor medium and DS recovery Diclofenac gel $5 \%$ was not equivalent to reference product Diclac $^{\circledR}$ gel $5 \%$. Such distinction can be attributed to both the different composition of the mixed solvent and, mainly, the different dispersed state of DS (Fig. 1,b), because only the dissolved substance diffuses through the membrane.

Fig. 14 shows release rate plots in the case of DS release from the gels with different IPA content; Table 13 provides the relevant release parameters. 


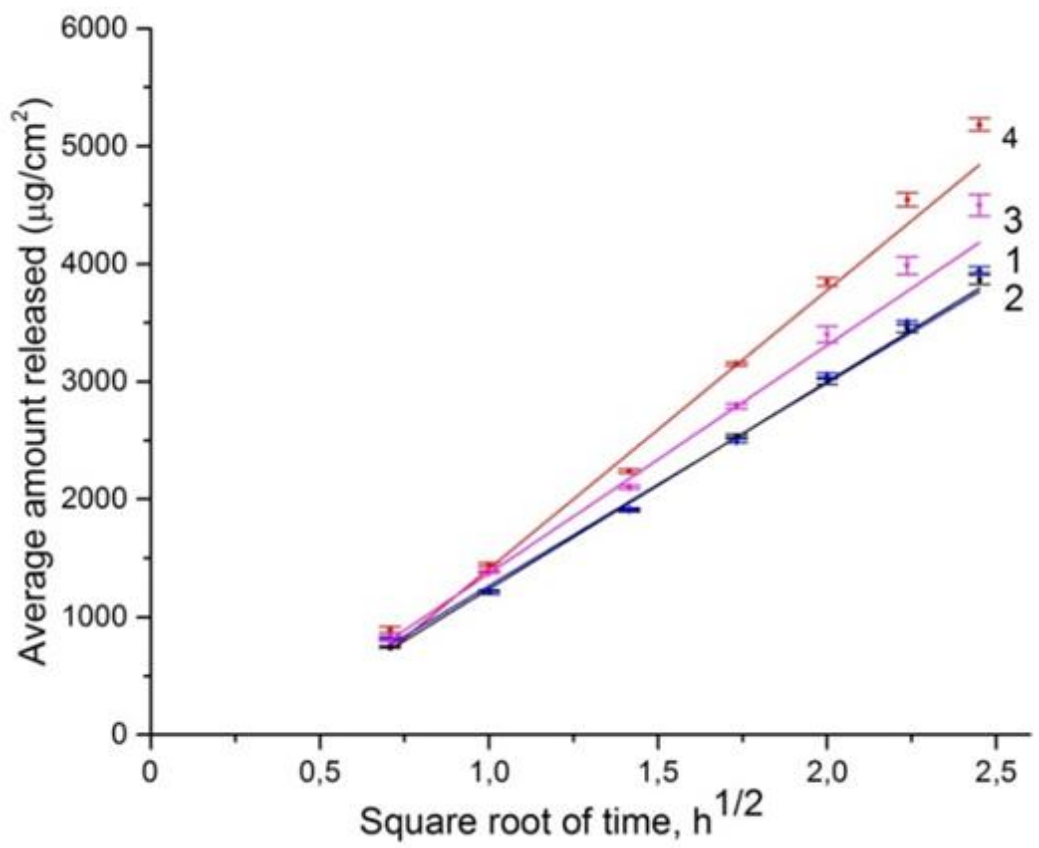

Fig. 14. DS release rate plots for the gels with DS content $5.0 \%$ and with IPA content $(\mathrm{g} / 100 \mathrm{~g})$ :

$1-45.0 ; 2-49.5 ; 3-40.5 ; 4-22.5$

Table 13

Parameters of DS release from the gels with DS content $5.0 \%$ and different IPA content

\begin{tabular}{|c|c|c|c|c|}
\hline \multirow[b]{2}{*}{ Parameter } & \multicolumn{4}{|c|}{ Value of the parameter of DS release when IPA content was: } \\
\hline & $45.0 \%$ IPA $(\mathbf{R})$ & $49.5 \% \operatorname{IPA}\left(\mathbf{T}_{\mathbf{1}}\right)$ & $40.5 \%$ IPA $\left(\mathbf{T}_{2}\right)$ & $22.5 \% \operatorname{IPA}\left(\mathbf{T}_{\mathbf{3}}\right)$ \\
\hline$R, \mu \mathrm{g} / \mathrm{cm}^{2} / \mathrm{h}^{-1 / 2}$ & $\begin{array}{l}1797.92 \pm 41.72 \\
\text { SD: } 20.71\end{array}$ & $\begin{array}{l}1809.95 \pm 20.71 \\
\text { SD: } 10.28\end{array}$ & $\begin{array}{c}2110.51 \pm 108.20 \\
\text { SD: } 53.70\end{array}$ & $\begin{array}{c}2476.62 \pm 46.17 \\
\text { SD: } 22.92\end{array}$ \\
\hline $\mathrm{A}, \mu \mathrm{g} / \mathrm{cm}^{2}$ & $\begin{array}{c}3865.75 \pm 79.28 \\
\text { SD: } 39.35\end{array}$ & $\begin{array}{c}3949.94 \pm 50.52 \\
\text { SD: } 25.07\end{array}$ & $\begin{array}{c}4501.15 \pm 182.42 \\
\text { SD: } 90.55\end{array}$ & $\begin{array}{c}5183.52 \pm 111.19 \\
\text { SD: } 55.18\end{array}$ \\
\hline $\mathrm{A}_{\mathrm{T}} / \mathrm{A}_{\mathrm{R}}, \%$ & & $101.28-102.83$ & $114.08-118.74$ & $132.60-135.68$ \\
\hline$R_{\mathrm{T}} / R_{\mathrm{R}}, \%$ & & $99.64-101.68$ & $114.60-119.85$ & $136.41-139.54$ \\
\hline $\mathrm{C}, \mu \mathrm{g} / \mathrm{ml}$ & $\begin{array}{c}455.00 \pm 9.34 \\
\text { SD: } 4.63\end{array}$ & $\begin{array}{c}465.11 \pm 5.95 \\
\text { SD: } 2.95\end{array}$ & $\begin{array}{l}530.01 \pm 21.48 \\
\text { SD: } 10.66\end{array}$ & $\begin{array}{c}610.36 \pm 13.09 \\
\text { SD: } 6.50\end{array}$ \\
\hline $\mathrm{r}$ & $\begin{array}{c}0.99945 \\
\text { SD: } 0.00015\end{array}$ & $\begin{array}{c}0.99807 \\
\text { SD: } 0.00023\end{array}$ & $\begin{array}{c}0.99796 \\
\text { SD: } 0.00047\end{array}$ & $\begin{array}{c}0.99590 \\
\text { SD: } 0.00079\end{array}$ \\
\hline $\mathrm{R}^{2}$ & 0.999 & 0.996 & 0.996 & 0.992 \\
\hline Recovery, \% & $\begin{array}{c}18.21 \pm 0.37 \\
\text { SD: } 0.19\end{array}$ & $\begin{array}{c}18.60 \pm 0.24 \\
\text { SD: } 0.12\end{array}$ & $\begin{array}{c}21.20 \pm 0.86 \\
\text { SD: } 0.43\end{array}$ & $\begin{array}{c}24.41 \pm 0.52 \\
\text { SD: } 0.26\end{array}$ \\
\hline
\end{tabular}

The increasing the IPA content up to $49.5 \% \mathrm{w} / \mathrm{w}$ (by $10 \%$ compared to the nominal content) had almost no effect on the parameters of DS release. But in the case of decreasing of the IPA content by $10 \%$ and $50 \%$ compared to the nominal content in the gel No. 1 the values of those parameters were greater and they were more than the upper limit of $111 \%$ for gel $\mathrm{T}_{2}$ and more than the upper limit of $133.33 \%$ for gel $\mathrm{T}_{3}$ (Table 13). The higher IPA content in the gel, the greater the difference in osmotic pressure between the gel and the receptor medium. Therefore, a decrease in the IPA concentration should have led to a decrease in the parameters of passive diffusion of DS. However, the values of the parameters of DS release became greater (Table 13).

The mixed solvent water - IPA containing $52 \% \mathrm{w} / \mathrm{w}$ IPA $\left(\rho=0.8903 \mathrm{~g} / \mathrm{cm}^{3}\right.$ at $\left.32{ }^{\circ} \mathrm{C}\right)$ was included to the formulation of the gel No. 1. The saturated solution of DS in this mixed solvent at $32{ }^{\circ} \mathrm{C}$ could contain DS of $191.85 \mathrm{mg} / \mathrm{ml}$. The DS content in $2.58 \mathrm{~g}(2.90 \mathrm{ml})$ of this solvent, which had been included in $3.0 \mathrm{~g}$ of gel No. 1 in the donor chamber, was $\mathbf{5 1 . 7 2} \mathbf{~ m g / m l}$

The mixed solvent water - IPA containing $26 \% \mathrm{w} / \mathrm{w}$ IPA $\left(\rho=0.9506 \mathrm{~g} / \mathrm{cm}^{3}\right.$ at $\left.32{ }^{\circ} \mathrm{C}\right)$ was included to the formulation of the gel No. 2. The saturated solution of DS in such mixed solvent at $32{ }^{\circ} \mathrm{C}$ could contain DS of $152.66 \mathbf{~ m g} / \mathbf{m l}$. The DS content in $2.58 \mathrm{~g}(2.71 \mathrm{ml})$ of this solvent, which had been included in $3.0 \mathrm{~g}$ of gel No. 2 in the donor chamber, was $\mathbf{5 5 . 2 7} \mathbf{~ m g / m l}$.

Potentially in $2.58 \mathrm{~g}$ of mixed solvents water - IPA at of $32{ }^{\circ} \mathrm{C}$ could be dissolved $556.37 \mathrm{mg}$ and $414.32 \mathrm{mg}$ of DS, respectively.

The content of DS in the saturated solution in water at $32{ }^{\circ} \mathrm{C}$ is $\mathbf{2 6 . 4 4} \mathbf{~ m g / m l}$. The volume of the receptor medium $(60 \mathrm{ml})$, measured at $25{ }^{\circ} \mathrm{C}$, increases to $\mathbf{6 0 . 1 2 2} \mathbf{~ m l}$ at $32{ }^{\circ} \mathrm{C}$, where $\mathbf{1 5 8 9 . 6 3} \mathbf{~ m g}$ of DS could be dissolved.

The ratio of the amounts of DS that could be dissolved in the receptor medium and in the mixed solvents 
water-IPA, which are part of the gels No. 1 and No. 2, are $\mathbf{2 . 8 6}$ and $\mathbf{3 . 8 4}$, respectively, and differ from each other by $\mathbf{1 . 3 4}$ times. The release rate (R) of DS from gel No. 2 compared to gel No. 1 increased by $\mathbf{1 . 3 8}$ times, and the cumulative content (A) increased by $\mathbf{1 . 3 4}$ times (Table 13). It can be assumed that the decrease in the solubility of DS and the increase in the ratio between the potential solubility of DS in $60 \mathrm{ml}$ of water and in $3.0 \mathrm{~g}$ of gel contributed to increasing the release rate of DS.

Fig. 15 illustrates the release rate plots in the case of IPA release from the gel No. 1 and liquid No. 1 containing $45.0 \%$ IPA as well as from the gel No. 2 containing $22.5 \%$ IPA; Table 14 provides the relevant release parameters. The release rate of IPA from the gels (as opposed to the release rate of DS), as well as the cumulative amount of IPA in the receptor medium decreased in proportion to the decrease IPA content in the gels from $45.0 \%$ to $22.5 \%$ (Tab. 14, Fig. 15). This confirmed the sensitivity and selectivity of the IVRT procedure and probably indirectly was evidence of another mechanism for increasing the release of DS with decreasing IPA content.

The liquid No. $1\left(\mathrm{~T}_{1}\right)$ and the gel No. $1(\mathrm{R})$ were equivalent in regard to the in vitro release of IPA, in the same way as in the case of the in vitro release of DS (Table 11 and Table 14). The different flow behaviour and viscosity were insignificant factors regarding the in vitro release of IPA from gel No. 1 and liquid No. 1 .

Fig. 16 illustrates the kinetics of water absorption by the gel No. 1, liquid No. 1 and gel No. 2 throughout IVRT duration.

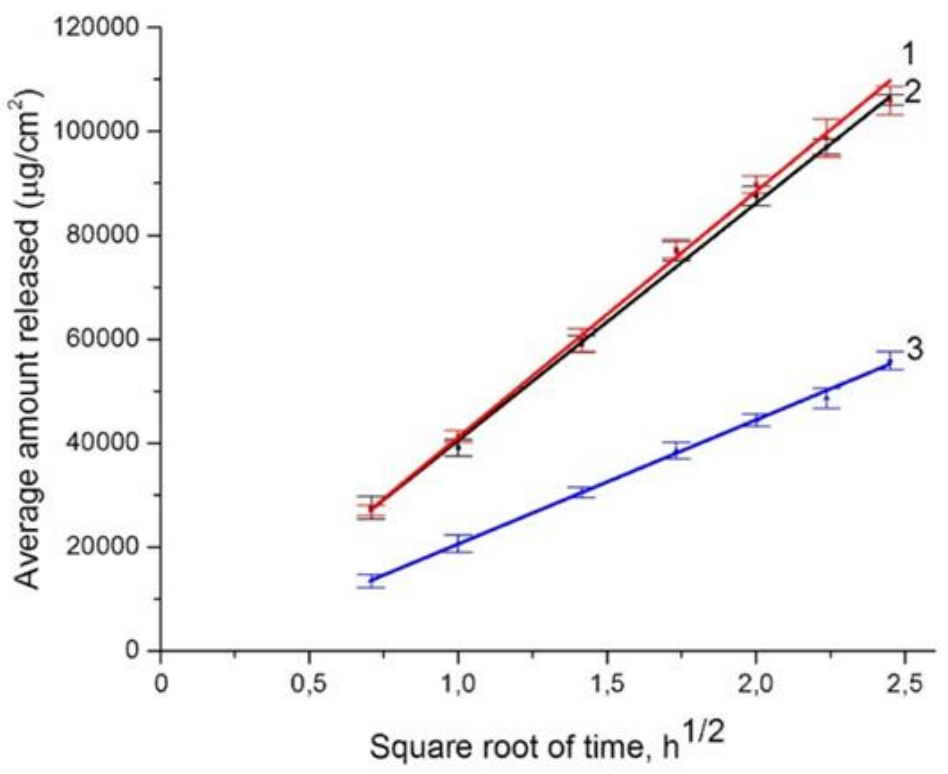

Fig. 15. IPA release rate plots for the gel No. 1 (1) and liquid No. 1 (2) containing $45.0 \%$ IPA as well as for gel No. 2 (3) containing $22.5 \%$ IPA

Parameters of IPA release from the gel No. $1(\mathbf{R})$ and liquid No. $1\left(\mathbf{T}_{1}\right)$ containing $45.0 \%$ IPA as well as for gel No. $2\left(\mathbf{T}_{2}\right)$ containing $22.5 \%$ IPA

\begin{tabular}{|l|c|c|c|}
\hline \multirow{2}{*}{\multicolumn{1}{|c|}{ Parameter }} & \multicolumn{3}{|c|}{ Value of the parameter of IPA release for: } \\
\cline { 2 - 4 } & Gel No. $1(\mathbf{R})$ & Liquid No. $1\left(\mathbf{T}_{\mathbf{1}}\right)$ & Gel No. $2\left(\mathbf{T}_{\mathbf{2}}\right)$ \\
\hline \multirow{2}{*}{ Release rate $(R), \mu \mathrm{g} / \mathrm{cm}^{2} / \mathrm{h}^{-1 / 2}$} & $46.02 \pm 1.61$ & $46.27 \pm 3.43$ & $23.81 \pm 2.53$ \\
& SD: 0.80 & SD: 1.70 & SD: 1.26 \\
\hline Cumulative amount $(\mathrm{A})$ & $106.07 \pm 1.96$ & $105.93 \pm 5.58$ & $55.89 \pm 3.50$ \\
(at the time point $6 \mathrm{~h}), \mu \mathrm{g} / \mathrm{cm}^{2}$ & SD: 0.97 & SD: 2.77 & SD: 1.74 \\
\hline $\mathrm{A}_{\mathrm{T}} / \mathrm{A}_{\mathrm{R}}, \%$ & & $97.66-102.24$ & $51.23-54.06$ \\
\hline$R_{\mathrm{T}} / R_{\mathrm{R}}, \%$ & & $97.55-103.78$ & $46.19-54.21$ \\
\hline $\mathrm{IPA}$ content $(\mathrm{C})$ in the receptor medium & $12.49 \pm 0.23$ & $12.47 \pm 0.66$ & $6.58 \pm 0.41$ \\
(at the time point $6 \mathrm{~h}), \mu \mathrm{g} / \mathrm{ml}$ & SD: 0.11 & SD: 0.33 & SD: 0.20 \\
\hline \multirow{2}{*}{ Correlation coefficient $\mathrm{r}$} & 0.99766 & 0.99682 & 0.99690 \\
& SD: 0.00104 & SD: 0.00189 & SD: 0.00157 \\
\hline Coefficient of determination $\mathrm{R}^{2}$ & 0.995 & 0.994 & 0.994 \\
\hline \multirow{2}{*}{ Recovery of IPA (at the time point $6 \mathrm{~h}), \%$} & $55.51 \pm 1.02$ & $55.44 \pm 2.92$ & $58.24 \pm 3.65$ \\
& SD: 0.51 & SD: 1.45 & SD: 1.81 \\
\hline
\end{tabular}




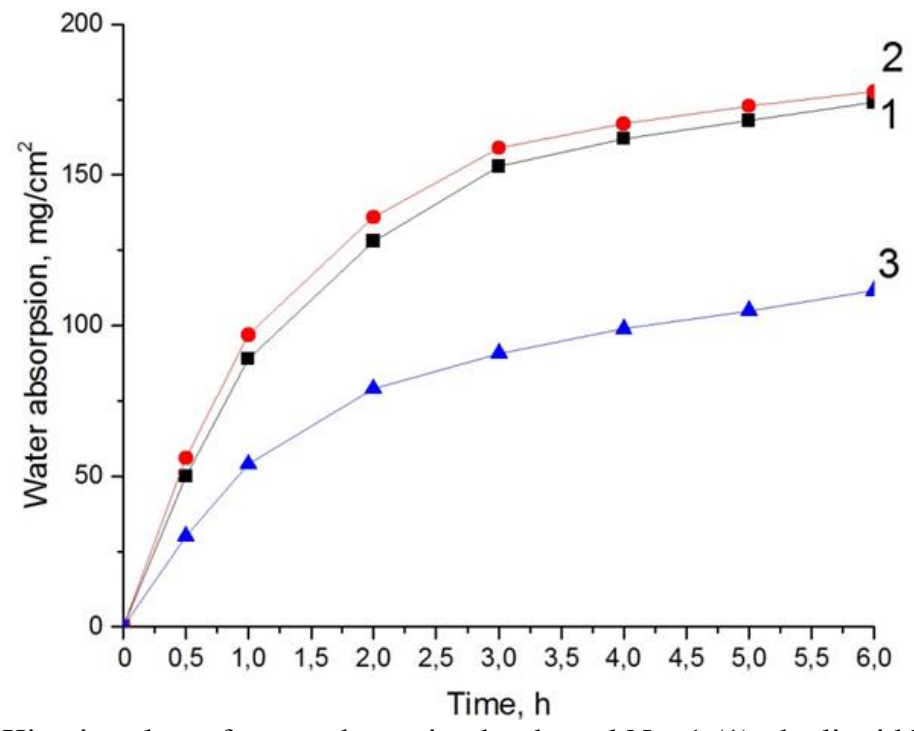

Fig. 16. Kinetics plots of water absorption by the gel No. 1 (1), the liquid No. 1 (2) and the gel No. 2 (3) during IVRT run at $32{ }^{\circ} \mathrm{C}$

The difference in osmotic pressure between the gel/liquid and water, which were separated by the membrane, led to bidirectional diffusion processes:

1) DS and IPA penetrated into the receptor chamber with water;

2) water penetrated into the donor chamber with gel or liquid.

The amount of water absorbed was increasing over time, but the rate of water absorption was gradually decreasing. The kinetics of water absorption by gel No. 1 and liquid No. 1 was almost identical. The cumulative amount of water (A) for them differed by only $2.1 \%$ at the end of 6-hour experiment. At IPA content of $22.5 \%$, the diffusion of water through the membrane was less intense, and the cumulative amount of water became lower by $35.9 \%$. During 6-hour IVRT test the gel No. 1, which mass was $3.0 \mathrm{~g}$, absorbed $1.23 \mathrm{~g}$ of water that was partially compensated by the diffusion of DS $(0.03 \mathrm{~g})$ and IPA $(0.75 \mathrm{~g}) .0 .45 \mathrm{~g}$ of water absorbed for $6 \mathrm{~h}$ was just about $0.75 \%$ by mass of the receptor medium and it did not adversely affect the results of IVRT.

\section{Discussion of research results}

HPMC of the certain types in gels performs function of a gelling agent, i.e. an excipient that contributes to increase of viscosity. The sol $\rightarrow$ gel transition, which occurred when HPMC was dissolved in the Newtonian fluid, led to a change in the flow behaviour and to significant increase in rheological parameters, in particular, the apparent viscosity (Table 2, Fig. 2 and Fig. 4). However, the formation of HPMC-based gels did not affect the state of the EPR spectra of dissolved spin probes, which remained identical to the EPR spectra of these spin probes in water and showed the rapid isotropic rotation of molecular radicals in both gels and water (Tables 3-5, Fig. 3,5$)$. The rotational correlation times $\left(\tau_{-1}\right)$ of spin probes (and, accordingly, the viscosity of their local surrounding) in gels and liquids differed within the error in determination. That is, in gel, spin probes rotated in a liquid medium whose polarity and viscosity were identical to the polarity and viscosity of liquid dispersion medium. It could be the prerequisite for the rapid and com- plete release of active substances from HPMC-based gels. It should also be noted that almost identical rotational correlation times of each of the spin probes with a certain functional group in water and gel indicated the absence of significant dipole-dipole or ion-dipole interactions with HPMC (Table 3), which could affect the release of active substances with same functional groups in their molecules.

The conclusions based on the results of the studies by spin probe method were confirmed by data regarding in vitro release of DS and IPA. The correctness of the analytical procedures for the quantitative determination of DS and IPA as well as the IVRT procedure was proved by the results of validation studies. Gel No. 1 and liquid No. 1 were equivalent in terms of the parameters of in vitro release of DS and IPA (Tables 11, 14, Fig. 12, 15). That is, presence of HPMC in the gel and the high apparent viscosity of the gel had no effect on the release of DS and IPA, and the HPMC performed the sole function of a modifier of the flow behaviour and viscosity.

The factors influenced the in vitro release of DS were the content and dispersed state of DS in the gel. If the DS was in the dissolved state, then with increasing DS content from $2.5 \%$ to $5.0 \%$ and up to $7.5 \%$, the release parameters changed proportionally (Table 9, Fig. 9). If DS was partially in the form of a dispersed phase of the suspension (Fig. 1), it led to a decrease in the parameters of in vitro release of DS (Table 12, Fig. 13). On the contrary, the same dispersed state of the active substance (as solution) and the same formulations ensure equivalence of medicinal products regarding in vitro release of DS (Table 12, Fig. 13).

The significant factor for the in vitro release of DS was the IPA content in the gel. When the IPA content in the gel was reduced by $10 \%$ and $50 \%$ of the nominal one, the in vitro release rate of IPA decreased proportionally, however, the in vitro release rate of DS, on the contrary, increased (Table 13, Fig. 14).

Assessing the release rates the gels with IPA content of $40.5 \%$ i $22.5 \%$ were non-equivalent compared to the gel with nominal IPA content of $40.5 \%$ according to the acceptance criteria established EMA and USP 
$[16,17]$. Therefore, the IPA content should be standardized with limits $\pm 5 \%$ of the nominal content to avoid the risk of production of non-equivalent batches. The increase in the release rate and the cumulative amount of DS with decreasing concentration of osmotically active IPA can probably be explained by a decrease in the solubility of DS in gel and an increase in the ratio between the potential solubility of DS in $60 \mathrm{ml}$ of receptor medium (water) and in $3.0 \mathrm{~g}$ of gel at $32{ }^{\circ} \mathrm{C}$.

It should also be emphasized that some other properties of the gel No. 1, for example, the density, depended on the concentration of IPA (Table 15). But, probably, this attribute did not affect the in vitro release kinetics of DS; significant factor for the release was the solubility of DS, which depended on the IPA content. So, IPA content should be strictly standardized.

Table 15

Density of the samples of gel No. 1 with different content of IPA (at $20^{\circ} \mathrm{C}$ )

\begin{tabular}{|l|c|}
\hline IPA content $(\mathrm{g} / 100 \mathrm{~g})$ & Density of the gel $\left(\mathrm{g} / \mathrm{cm}^{3}\right)$ \\
\hline $40.50(90 \%)^{*}$ & 0.946 \\
\hline $42.75(95 \%)^{*}$ & 0.942 \\
\hline $45.00(100 \%)^{*}$ & 0.936 \\
\hline $47.25(105 \%)^{*}$ & 0.930 \\
\hline $49.50(110 \%)^{*}$ & 0.925 \\
\hline
\end{tabular}

Note: *The amount (\%) of IPA from the nominal content of $45.00 \mathrm{~g} / 100 \mathrm{~g}$

According to specification for the Diclac ${ }^{\circledR}$ gel $5 \%$ its density should be tested not the content of IPA, although this substance is a penetration enhancer and antimicrobial preservative as well as affects the DS release [2]. Such approach does not meet the provisions of European quality guidelines [27, 29]. Therefore, during equivalence investigation using in vitro experiments, the IPA content in the test samples of the reference product Diclac $^{\circledR}$ gel $5 \%$ and a generic product should be determined using a validated analytical procedure.

For the equivalence investigation using in vitro experiments at the stage of pharmaceutical development, it is necessary to identify factors relevant to the release of the active substance.

\section{Conclusions}

The apparent viscosity of the gels increased with increasing HPMC content and depended on the HPMC grade. It was shown that high apparent viscosity of the gels did not affect the values of $\tau_{-1}$ of the dissolved spin probes. In viscous gels and Newtonian fluids, the composition of which corresponded to the dispersion medium of gels, the values of $\tau_{-1}$ were identical and were in the range of rapid rotation, which is a prerequisite for similar and rapid release of the dissolved substances from gels and liquids. It was shown that the HPMC-based gel and Newtonian liquid without HPMC in terms of in vitro release parameters DS and IPA were equivalent. During in vitro testing the release of dissolved DS increased with increasing its concentration in the gel and depended on the dispersed state of DS. When the content of IPA was changed from $45.0 \%$ to $22.5 \%$, the water absorption by the gel and the release of IPA decreased, and the release of DS increased, which was due to the decrease in the solubility of DS in the gel.

\section{Conflict of interests}

The authors declare that they have no conflicts of interest.

\section{Financing}

The study was performed without financial support.

References

1. The European Pharmacopoeia (2019). European Directorate for the Quality of Medicines \& HealthCare of the Council of Europe. Strasbourg, 5224.

2. Sheskey, P. J., Hancock, B. C., Moss, G. P., Goldfarb, D. J. (Eds.) (2020). Handbook of Pharmaceutical Excipients. London: Pharm. Press, 1296.

3. Lyapunov, A. N., Bezuglaya, E. P., Lyapunov, N. A., Kirilyuk, I. A. (2015). Studies of Carbomer Gels Using Rotational Viscometry and Spin Probes. Pharmaceutical Chemistry Journal, 49 (9), 639-644. doi: http://doi.org/10.1007/s11094-015-1344-3

4. Mašková, E., Kubová, K., Raimi-Abraham, B. T., Vllasaliu, D., Vohlídalová, E., Turánek, J., Mašek, J. (2020). Hypromellose - A traditional pharmaceutical excipient with modern applications in oral and oromucosal drug delivery. Journal of Controlled Release, 324, 695-727. doi: http://doi.org/10.1016/j.jconrel.2020.05.045

5. Kolli, S., Vijaya, K., Murthy, P. N., Sirisha, K. V. R. (2018). Solubility Enhancement of Itraconazole by Hypromellose Formulated by Solution-Suspension Layering Technique. Research Journal of Pharmacy and Technology, 11 (11), 4850-4853. doi: http://doi.org/10.5958/0974-360x.2018.00882.x

6. Dharmalingam, K., Anandalakshmi, R. (2019). Fabrication, characterization and drug loading efficiency of citric acid crosslinked NaCMC-HPMC hydrogel films for wound healing drug delivery applications. International Journal of Biological Macromolecules, 134, 815-829. doi: http://doi.org/10.1016/j.ijbiomac.2019.05.027

7. Asare-Addo, K., Kaialy, W., Levina, M., Rajabi-Siahboomi, A., Ghori, M. U., Supuk, E. et. al. (2013). The influence of agitation sequence and ionic strength on in vitro drug release from hypromellose (E4M and K4M) ER matrices - The use of the USP III apparatus. Colloids and Surfaces B: Biointerfaces, 104, 54-60. doi: http://doi.org/10.1016/j.colsurfb.2012.11.020

8. Mason, L. M., Campiñez, M. D., Pygall, S. R., Burley, J. C., Gupta, P., Storey, D. E. et. al. (2015). The influence of polymer content on early gel-layer formation in HPMC matrices: The use of CLSM visualisation to identify the percolation threshold. European Journal of Pharmaceutics and Biopharmaceutics, 94, 485-492. doi: http://doi.org/10.1016/j.ejpb.2015.06.019

9. Franek, F., Holm, P., Larsen, F., Steffansen, B. (2014). Interaction between fed gastric media (Ensure Plus ${ }^{\mathbb{B}}$ ) and different hypromellose based caffeine controlled release tablets: Comparison and mechanistic study of caffeine release in fed and fasted media versus water using the USP dissolution apparatus 3. International Journal of Pharmaceutics, 461 (1-2), 419-426. doi: http://doi.org/10.1016/ j.ijpharm.2013.12.003

10. Ghori, M. U., Ginting, G., Smith, A. M., Conway, B. R. (2014). Simultaneous quantification of drug release and erosion from hypromellose hydrophilic matrices. International Journal of Pharmaceutics, 465 (1-2), 405-412. doi: http://doi.org/10.1016/ j.ijpharm.2014.02.028

11. Derzhavnyi reiestr likarskykh zasobiv Ukrainy. Available at: http://www.drlz.kiev.ua/

12. Gosudarstvennii reestr lekarstvennykh sredstv (GRLS). Available at: http://grls.rosminzdrav.ru

13. Altman, R., Bosch, B., Brune, K., Patrignani, P., Young, C. (2015). Advances in NSAID Development: Evolution of Diclofenac Products Using Pharmaceutical Technology. Drugs, 75 (8), 859-877. doi: http://doi.org/10.1007/s40265-015-0392-z 
14. Buckingham, R. (Ed.) (2020). Martindale: The Complete Drug Reference. London: Pharmaceutical Press, 4912.

15. Seefried, L., Blyth, M., Maheshwari, R., McDonnell, S. M., Frappin, G., Hagen, M., Maybaum, N. Moreira, S., Pandit H. (2020). Penetration of topical diclofenac into synovial tissue and fluid of osteoarthritic knees: a multicenter, randomized, placebocontrolled, pharmacokinetic study. Therapeutic Advances in Musculoskeletal Disease, 12, 1-13. doi: 10.1177/1759720X20943088

16. The United States Pharmacopoeia, 41 - NF 36 (2018). The United States Pharmacopoeial Convention. Rockville. Available at: https://www.worldcat.org/title/united-states-pharmacopeia-2018-usp-41-the-national-formulary-nf-36/oclc/1013752699

17. Draft guideline on quality and equivalence of topical products (2018). CHMP/QWP/708282/2018. Available at: www.ema.europa.eu/en/quality-equivalence-topical-products

18. Ilić, T., Pantelić, I., Savić, S. (2021). The Implications of Regulatory Framework for Topical Semisolid Drug Products: From Critical Quality and Performance Attributes towards Establishing Bioequivalence. Pharmaceutics, 13 (5), 710. doi: http://doi.org/10.3390/pharmaceutics13050710

19. Nonsterile Semisolid Dosage Forms Scale-Up and Postapproval Changes: Chemistry, Manufacturing, and Controls (1997). In Vitro Release Testing and In Vivo Bioequivalence Documentation. Guidance for Industry. U.S. Department of Health and Human Services; Food and Drug Administration Center for Drug Evaluation and Research (CDER), 37.

20. Maanvizhi, S., Iyyappan, V., Bhavishi, P. G. (2020). In-vitro release study of Diclofenac sodium from topical gel formulations using diffusion cell. Research Journal of Pharmacy and Technology, 13 (6), 2901-2905. doi: http://doi.org/10.5958/0974-360x.2020.00517.x

21. Pleguezuelos-Villa, M., Merino-Sanjuán, M., Hernández, M. J., Nácher, A., Peris, D., Hidalgo, I. et. al. (2019). Relationship between rheological properties, in vitro release and in vivo equivalency of topical formulations of diclofenac. International Journal of Pharmaceutics, 572, 118755. doi: http://doi.org/10.1016/j.ijpharm.2019.118755

22. Alkilani, A., McCrudden, M. T., Donnelly, R. (2015). Transdermal Drug Delivery: Innovative Pharmaceutical Developments Based on Disruption of the Barrier Properties of the Stratum Corneum. Pharmaceutics, 7 (4), 438-470. doi: http://doi.org/10.3390/ pharmaceutics7040438

23. Derzhavna Farmakopeia Ukrainy. Vol. 1 (2015). Kharkiv: Derzhavne pidpryiemstvo «Ukrainskyi naukovyi farmakopeinyi tsentr yakosti likarskykh zasobiv», 1128.

24. Likhtenshtein, G. I. (1974). Metod spinovykh zondov v molekuliarnoi biologii. Moscow: Nauka, 256.

25. Derzhavna Farmakopeia Ukrainy. Dopovnennia 4 (2020). Kharkiv: Derzhavne pidpryiemstvo «Ukrainskyi naukovyi farmakopeinyi tsentr yakosti likarskykh zasobiv», 600 .

26. Tiffner, K. I., Kanfer, I., Augustin, T., Raml, R., Raney, S. G., Sinner, F. (2018). A comprehensive approach to qualify and validate the essential parameters of an in vitro release test (IVRT) method for acyclovir cream, 5\%. International Journal of Pharmaceutics, 535 (1-2), 217-227. doi: http://doi.org/10.1016/j.ijpharm.2017.09.049

27. Note for Guidance Specifications: Test Procedures and Acceptance Criteria for New Drug Substances and New Drug Products: Chemical Substances (2000). CPMP/ICH/367/96 (ICH Topic Q6A).

28. Note for Guidance on Validation of Analytical Procedures: Text and Methodology, Step 5 (1995). CPMP/ICH/381/95 (ICH Topic Q 2 (R1) Validation of Analytical Procedures: Text and Methodology).

29. Guideline on Excipients in the Dossier for Application for Marketing Authorisation of a Medicinal Product (2007). EMEA/CHMP/QWP/396951/2006.

Received date 27.08.20221

Accepted date 19.10.2021

Published date 28.10.2021

Elena Bezuglaya*, PhD, Senior Researcher, Head of Laboratory, Laboratory of Technology and Analysis of Medicinal Products, State Scientific Institution "Institute for Single Crystals" of National Academy of Sciences of Ukraine, Nauky ave., 60, Kharkiv, Ukraine, 61072

Hanna Ivashchenko, Junior Researcher, Laboratory of Technology and Analysis of Medicinal Products, State Scientific Institution "Institute for Single Crystals" of National Academy of Sciences of Ukraine, Nauky ave., 60, Kharkiv, Ukraine, 61072

Nikolay Lyapunov, Doctor of Pharmaceutical Sciences, Professor, Leading Researcher, Laboratory of Technology and Analysis of Medicinal Products, State Scientific Institution "Institute for Single Crystals" of National Academy of Sciences of Ukraine, Nauky ave., 60, Kharkiv, Ukraine, 61072

Igor Zinchenko, PhD, Junior Researcher, Laboratory of Technology and Analysis of Medicinal Products, State Scientific Institution "Institute for Single Crystals" of National Academy of Sciences of Ukraine, Nauky ave., 60, Kharkiv, Ukraine, 61072

Anna Liapunova, PhD, Researcher, Laboratory of Technology and Analysis of Medicinal Products, State Scientific Institution "Institute for Single Crystals" of National Academy of Sciences of Ukraine, Nauky ave., 60, Kharkiv, Ukraine, 61072

Yurij Stolper, PhD, Senior Researcher of the Department, Laboratory of Technology and Analysis of Medicinal Products, State Scientific Institution "Institute for Single Crystals" of National Academy of Sciences of Ukraine, Nauky ave., 60, Kharkiv, Ukraine, 61072

Oleksii Liapunov, PhD, Researcher, Laboratory of Technology and Analysis of Medicinal Products, State Scientific Institution "Institute for Single Crystals" of National Academy of Sciences of Ukraine, Nauky ave., 60, Kharkiv, Ukraine, 61072

Tetiana Pukhova, Junior Researcher, Laboratory of Technology and Analysis of Medicinal Products, State Scientific Institution "Institute for Single Crystals" of National Academy of Sciences of Ukraine, Nauky ave., 60, Kharkiv, Ukraine, 61072

*Corresponding author: Elena Bezuglaya, e-mail: bezugla.op@gmail.com 